\title{
A NEW INTERNATIONAL HUMAN RIGHTS COURT FOR WEST AFRICA: THE ECOWAS COMMUNITY COURT OF JUSTICE
}

\author{
By Karen J. Alter, ${ }^{*}$ Laurence R. Helfer, ${ }^{\dagger}$ and Jacqueline R. McAllister ${ }^{\ddagger}$
}

The Community Court of Justice of the Economic Community of West African States (ECOWAS Court) is an increasingly active and bold adjudicator of human rights. Since acquiring jurisdiction over human rights complaints in 2005, the ECOWAS Court has issued numerous decisions condemning human rights violations by the member states of the Economic Community of West African States (Community). ${ }^{1}$ Among this Court's path-breaking cases ${ }^{2}$ are judgments against Niger for condoning modern forms of slavery and against Nigeria for impeding the right to free basic education for all children. ${ }^{3}$ The ECOWAS Court also has broad access and standing rules that permit individuals and nongovernmental organizations (NGOs) to bypass national courts and file suits directly with the Court. Although the Court is generally careful in the proof that it requires of complainants and in the remedies that it demands of governments, it has not shied away from politically courageous decisions, such as rulings against

\footnotetext{
* Professor of Political Science and Law, Northwestern University, and Permanent Visiting Professor, iCourts: The Danish National Research Foundation's Center of Excellence for International Courts. Email: kalter@northwestern.edu. The authors thank Kristina Alayan, Ethan Blevins, and Abraham Smith for excellent research assistance. For comments on earlier drafts, we thank the participants in conferences and workshops held at the American Society of International Law Research Forum at UCLA Law School; the Cegla Center for Interdisciplinary Research at the University of Tel Aviv; Duke University School of Law; iCourts; the Hauser Colloquium at New York University Law School; the Program of African Studies, Northwestern University; the University of St. Gallen; and the University of Wisconsin Regional Colloquium on Globalization and Law.

$\dagger$ Of the Board of Editors. Email: helfer@law.duke.edu.

‡ Ph.D. candidate, Department of Political Science, Northwestern University. Email: j-mcallister@u. northwestern.edu.

${ }^{1}$ Fifteen nations are currently members of ECOWAS: Benin, Burkina Faso, Cape Verde, Côte d'Ivoire, the Gambia, Ghana, Guinea, Guinea-Bissau, Liberia, Mali, Nigeria, Senegal, Sierra Leone, and Togo.

${ }^{2}$ A list of all judgments and rulings of the ECOWAS Court, as well as copies of selected decisions, are available on the Court's website. ECOWAS Community Court of Justice, List of Decided Cases from 2004 Till Date, at http://www.courtecowas.org/site2012/index.php?option=com_content\&view=article\&id=157\&Itemid=27. The first five years of judgments and rulings have been published in an official reporter, but it is not widely available. 2004-2009 COMMUNITY COURT OF JUSTICE, ECOWAS LAW REPORT (2011). Selected decisions, some in unofficial translation, are available on other online databases. E.g., Centre for Human Rights, University of Pretoria, African Human Rights Case Law Database, at http://www1.chr.up.ac.za/index.php/browse-by-institution/ ecowas-ccj.html; WorldCourts, ECOWAS Community Court of Justice: Decisions, at http://www.worldcourts.com/ ecowasccj/eng/.

${ }^{3}$ E.g., Lydia Polgreen, Court Rules Niger Failed by Allowing Girl's Slavery, N.Y. TiMES, Oct. 28, 2008, at A6; ECOWAS Court Orders Gambia to Pay Musa Saidykhan \$200,000 in Landmark Case, JOLLOFNEWS (Dec. 16, 2010), at http://www.jollofnews.com/human-rights/1629-ecowas-court-orders-gambia-to-pay-musa-saidykhan200000-?in-landmark-case-; African Child Information Hub, West Africa: ECOWAS Court Orders Nigeria to Provide Free Education for Every Child (Dec. 2, 2010), at http://www.africanchildinfo.net/index.php?option=com $\mathrm{k} 2 \& \mathrm{view}=$ item \&id $=5046 \% 3$ Awest-africa-ecowas-court-orders-nigeria-to-provide-free-education-for-everychild\&Itemid=67\&lang=en\#; Amnesty International, Nigeria: Ground-Breaking Judgment Calls for Punishing Oil Companies over Pollution (Dec. 17, 2012), at http://www.amnesty.org/en/news/nigeria-ground-breakingjudgment-calls-punishing-oil-companies-over-pollution-2012-12-17.
} 
the Gambia for the torture of journalists and against Nigeria for failing to regulate multinational companies that have degraded the environment of the oil-rich Niger Delta.

Our primary goal in this article is to explain how an international tribunal, initially established to help build a common market, was redeployed as a human rights court. In particular, we ask why West African governments, which set up the ECOWAS Court in a way that has allowed persistent flouting of Community economic rules, later delegated to ECOWAS judges remarkably far-reaching human rights jurisdiction.

The ECOWAS Court's transformation is surprising in many ways. By all accounts, ECOWAS has made little progress toward its professed goal of regional economic integration. Trade flows among West African nations remain extremely low; tariffs, customs regulations, nontariff barriers, and roadblocks hinder cross-border economic transactions; ${ }^{4}$ and member states have yet to challenge barriers to intraregional trade before the ECOWAS Court. If our story ended here, with a new international court struggling for relevance, few would be surprised. However, our story takes a sharp and unexpected turn in 2005 with an expansion of the Court's jurisdiction to include human rights complaints by private litigants.

When we began our study, we had low expectations for the ECOWAS Court. Human rights violations, destabilizing coups, and civil unrest are sadly commonplace in West Africa, and domestic legal institutions are generally weak. ${ }^{5}$ We anticipated that national governments in such a region would resist giving an international court the power to review human rights claims from private litigants. And if officials did give the court such authority, we expected that they would put in place political checks to carefully control the judges and their decisions. What we found-based on a review of ECOWAS Court decisions and more than two dozen interviews with judges, Community officers, government officials, attorneys, and $\mathrm{NGOs}^{6}$ was quite different. The member states gave the ECOWAS Court a broad human rights jurisdiction, and they have eschewed opportunities to narrow the Court's authority.

The ECOWAS Court's repurposing and subsequent survival as an international human rights court have several unexpected dimensions. First, the Court did not claim human rights competence for itself via judicial lawmaking. Rather, it acquired this authority in response to a coordinated campaign in which bar associations, NGOs, and ECOWAS officials - in addition to ECOWAS Court judges themselves-mobilized to secure member states' consent to the transformation. Second, the Court has strikingly capacious jurisdiction and access rules, with no specified catalogue of human rights, with direct access for private litigants, and with no requirement to exhaust domestic remedies. These design features are especially curious because West African states have been reluctant to grant similar authority to the judicial institutions

\footnotetext{
${ }^{4}$ S. K. B. Asante, Economic Community of West African States, in THE OXFORD COMPANION TO POLITICS OF THE WORLD 233, 234 (Joël Krieger ed., 2d ed. 2001).

${ }^{5}$ See, e.g., Emmanuel Kwesi Aning, Investing in Peace and Security in Africa: The Case of ECOWAS, in SECURITY AND DEVELOPMENT: INVESTING IN PEACE AND PROSPERITY 337, 351 (Robert Picciotto \& Rachel Weaving eds., 2006); Eghosa E. Osaghae, Human Rights and Transition Societies in West Africa, in HUMAN RIGHTS AND SOCIETIES IN TRANSITION: CAUSES, CONSEQUENCES, RESPONSES 315, 315 (Shale Asher Horowitz \& Albrecht Schnabel eds., 2004); ISSAKA K. SOUARÉ, CIVIL WARS AND COUPS D’ÉTAT IN WEST AFRICA: AN ATTEMPT TO UNDERSTAND THE ROOTS AND PRESCRIBE POSSIBLE SOLUTIONS 135 (2006).

${ }^{6}$ To preserve anonymity in accordance with the approval granted by our universities' institutional review boards, unless expressly requested by our sources, the names of our interviewees have been redacted. Each interview is identified here by date, location, and category, and by a unique identifying letter that is used in our records of all interviews.
} 
of the African Charter on Human and Peoples' Rights ${ }^{7}$ (African Charter).Third, when the ECOWAS Court's early rulings generated opposition from some governments, the member states eschewed opportunities to rein in the Court. Instead, they adopted institutional reforms that arguably strengthen the judges' independence and authority. Nevertheless, the Court faces an ongoing challenge of securing compliance with its judgments, a challenge that the judges are attempting to meet by tailoring the remedies that they award to successful applicants and by publicly pressuring governments to implement the Court's rulings.

Our study of the ECOWAS Court's transformation has two broader theoretical implications. ${ }^{8}$ The first relates to how international institutions, including courts, evolve over time. Rationalist theories of cooperation generally conceive of international institutions as problemsolving devices to further states' functional goals. We contrast rationalist approaches that tether institutions to the states that created them to historical institutionalist accounts that expect institutions to evolve in response to political contestation and societal pressures. States nevertheless play an important part in our narrative, particularly through their decisions in the 1990 s to authorize humanitarian intervention in West Africa and expand ECOWAS's regional security role. We argue that these decisions triggered a cascade of smaller reforms in the Community that, in the mid-2000s, created an opening for an alliance of civil society groups and supranational actors to mobilize in favor of court reform.

A second theoretical implication relates to the repurposing of international courts. The ECOWAS Court's shift into human rights is not unique. The European Court of Justice (ECJ) made an equivalent shift in the 1970s. More recently, courts associated with other subregional economic communities - most notably, the East African Court of Justice (EACJ) and the Tribunal of the Southern African Development Community (SADC Tribunal) — have made similar moves. In all three instances, however, the judges themselves asserted the authority to adjudicate human rights claims. In Africa, the political and legal consequences of these bold assertions of competence are still unfolding, but early evidence indicates that the EACJ and the SADC Tribunal have faced greater opposition from governments than has the ECOWAS Court. ${ }^{9}$ We argue that the manner by which an international court acquires a human rights jurisdiction matters, for reasons we will elaborate.

The remainder of this article proceeds as follows. Part I reviews the founding of ECOWAS and the ECOWAS Court, and the expansion of the Community's role in regional security. We explain that member states added a tribunal to ECOWAS as part of a wider re-launch of regional integration in the early 1990s. Yet they also rejected a proposal to give private litigants access to the Court to facilitate enforcement of regional economic rules. As a result, the Court sat unused for several years.

\footnotetext{
${ }^{7}$ African (Banjul) Charter on Human and Peoples' Rights, June 27, 1981, 1520 UNTS 217, 21 ILM 58 (1982) [hereinafter African Charter].

${ }^{8}$ This theoretical account builds on our prior work. See, e.g., KAREN J. ALTER, THE NEW TERRAIN OF INTERNATIONAL LAW: COURTS, POLITICS, RIGHTS (forthcoming 2014); Karen J. Alter \& Laurence R. Helfer, Nature or Nurture? Judicial Law-Making in the European Court of Justice and the Andean Tribunal ofJustice, 64 INT'L ORG. 563 (2010); Laurence R. Helfer \& Anne-Marie Slaughter, Toward a Theory of Effective Supranational Adjudication, 107 YALE L.J. 273 (1997).

${ }^{9}$ E.g., Solomon Tamarabrakemi Ebobrah, Litigating Human Rights Before Sub-regional Courts in Africa, 17 AFR. J. INT'L \& COMP. L. 79 (2009); James Gathii, The Under-appreciated Jurisprudence of Africa's Regional Trade Judiciaries, 12 OR. REV. INT'L L. 245 (2010); Lucyline Nkatha Murungi \& Jacqui Gallinetti, The Role of Sub-regional Courts in the African Human Rights System, 7 INT'L J. HUM. RTS. 119 (2010).
} 
Part II begins by summarizing the dismissal of the ECOWAS Court's first case-a suit by a private trader challenging a border closure. The case served as the catalyst for a campaign by bar associations, NGOs, Community officials, and ECOWAS judges, which resulted in the 2005 Protocol that gives the Court broad human rights jurisdiction. ${ }^{10}$ After summarizing the rationales and mobilization campaign behind the 2005 Protocol, we analyze three distinctive features of the restructured Court's design-direct access for private parties, the absence of ECOWAS-specific human rights standards, and non-exhaustion of domestic remedies.

In part III we evaluate the ECOWAS Court's track record as a human rights tribunal. We focus on three major challenges to the Court's authority-a controversial election decision that engendered criticism from the public and legal elites in Nigeria; a proposal by the Gambia to narrow the Court's jurisdiction in response to rulings declaring the government responsible for torture; and concerns relating to noncompliance with ECOWAS Court rulings. We explain how the Court has weathered these challenges by mobilizing supportive constituencies, adjusting the remedies it orders, and publicly cajoling governments to implement its decisions.

Part IV considers the theoretical implications of our analysis, contrasting rationalist international relations and historical institutionalist theories of institutional change. We explain how the strategy that advocates adopted - conflating the economic goals of ECOWAS with its human rights objectives - contributed to the ironic result that an international court established to promote regional integration now adjudicates cases involving high-profile human rights violations while remaining largely unavailable to traders and other economic actors in the region.

In part $\mathrm{V}$, we conclude by assessing the implications of the ECOWAS Court's transformation for the survival prospects of Africa's other subregional courts and for broader debates about fragmentation and the coherent interpretation of international human rights law.

\section{ThE POLITICAL, LEGAL, AND INSTITUTIONAL FRAMEWORK OF ECOWAS AND ITS COMMUNITY COURT OF JUSTICE}

This part discusses the motives for establishing an economic integration regime in West Africa and why the commitment of ECOWAS member states to this regime has remained shallow. We then explain how, in the 1990s, the Community became involved in regional security and good governance issues, which later created a political opening to transform the ECOWAS Court. We conclude by linking the creation of the Court to these developments and explaining the member states' rejection of a proposal to grant private litigants direct access to the Court.

\section{The Founding of ECOWAS and the Barriers to Economic Integration in West Africa}

Why were West African governments interested in economic integration? At the founding of ECOWAS in 1975, the Community's primary goals, as defined by the Treaty, were to promote cooperation and development in a wide array of issue areas, including commerce, agriculture, natural resources, monetary and financial policy, security, and social and cultural mat-

${ }^{10}$ Supplementary Protocol A/SP1/01/05 Amending the Preamble and Articles 1, 2, 9 and 30 of Protocol (A/P.1/7/91) Relating to the Community Court of Justice and Article 4 Paragraph 1 of the English Version of the Said Protocol, Jan. 19, 2005 [hereinafter 2005 Protocol], at http://www.courtecowas.org/site2012/pdf_files/ supplementary_protocol.pdf. 
ters. ${ }^{11}$ The project included removing intraregional trade barriers, reflecting the conventional view that open markets attract foreign investment and encourage development. Member states understood from the project's inception, however, that integration of national markets would be only one of many ECOWAS objectives. ${ }^{12}$

The names given to ECOWAS institutions mimicked their European Community counterparts. In reality, however, the 1975 ECOWAS Treaty created a system of policymaking bodies that governments tightly controlled. The principal Community institutions included an Authority of Heads of State and Government (Authority), the highest ECOWAS decisionmaking body; a Council of Ministers, which served in an advisory capacity to the Authority; and an Executive Secretariat responsible for the day-to-day administration of ECOWAS policies. These bodies adopted initiatives that, on paper, committed governments to phase out quantitative and other restrictions on intraregional trade, create a customs union, establish a common commercial policy, and permit the free movement of goods and persons. ${ }^{13}$

In reality, the legal framework required to carry out these policies was lacking. The institutions created by the 1975 Treaty, unlike those of the European Community, "left national sovereignty intact." ${ }^{14}$ The decisions of the Authority and the Council of Ministers were binding only on ECOWAS institutions. They had no legal force for member states, which had merely agreed to "make every effort to plan and direct their policies with a view to creating favourable conditions for the achievement of" the Community's aims. ${ }^{15}$ In the absence of delegated supranational decision-making powers, ECOWAS policies were formulated using a standard tool of public international law - a series of protocols adopted unanimously that accorded each government discretion with respect to ratification and implementation, and that entered into force only after a majority of countries had ratified. This cumbersome and politicized decision-making process was a "slow and inadequate" mechanism for Community lawmaking. ${ }^{16}$

At a deeper level, there was also good reason to question the economic and political logic of a West African integration project. ECOWAS countries are geographically proximate, and instability in one nation can easily destabilize neighboring countries. But in other respects, the divisions among the member states were and remain profound. Regional infrastructure is woefully underdeveloped, which makes intraregional trade costly. ${ }^{17}$ Francophone countries are deeply linked to France's economic and political system, whereas Nigeria and Ghana— the two

\footnotetext{
${ }^{11}$ Treaty of the Economic Community of West African States, May 28, 1975, 1010 UNTS 17, 14 ILM 1200.

12 The economic theory motivating the creation of ECOWAS is discussed in KOFI OTENG KUFUOR, THE INSTITUTIONAL TRANSFORMATION OF THE ECONOMIC COMMUNITY OF WEST AFRICAN STATES 2-8 (2006).

${ }^{13}$ Charles D. Jebuni, The Role of ECOWAS in Trade Liberalization, in TRADE REFORM AND REGIONAL INTEGRATION IN AFRICA 489, 493 (Zubair Iqbal \& Mohsin S. Khan eds., 1998).

${ }^{14}$ Committee of Eminent Persons for the Review of the ECOWAS Treaty, Final Report 16 (June 1992) [hereinafter Final CEP Report] (on file with authors).

15 Treaty of the Economic Community of West African States, supra note 11, Art. 3.

${ }^{16}$ S. K. B. Asante, The Political ECONOMy of Regionalism in AFrica: A DeCADE of THE ECONOMIC COMMUNITY OF WEST AFRICAN STATES (ECOWAS) 70 (1986); see also MUHAMMED TAWFIQ LADAN, INTRODUCTION TO ECOWAS COMMUNITY LAW AND PRACTICE: INTEGRATION, MIGRATION, HUMAN RIGHTS, ACCESS TO JUSTICE, PEACE AND SECURITY 7 (2009) (explaining that "most often, Community texts adopted in the so-called areas of sovereignty were in the form of protocols, and there was considerable delay in their application owing to the slow pace of protocol ratification").

${ }_{17}$ Chukwuma Agu, Obstacles to Regional Integration: The Human Factor Challenge to Trade Facilitation and Port Reforms in Nigeria, 2 INT'L J. PRIVATE L. 445 (2009).
} 
largest Anglophone economies — have different capabilities and economic goals. ${ }^{18}$ The key trading partners for West African countries are outside of the region, and the little intraregional trade that occurs involves natural resources, agricultural products, and low-value-added consumption products such as rubber, plastics, and cosmetics. ${ }^{19}$ Although some traders stand to benefit from easier access to regional markets, many local producers actively seek to avoid competition from firms in other ECOWAS countries. ${ }^{20}$

Building a common market in West Africa was nonetheless attractive for a different reason. The 1975 ECOWAS Treaty signaled to its poorer neighbors that Nigeria-the "big brother" 21 of West Africa, which then accounted for nearly 70 percent of the region's total GDP 22 -favored regional cooperation. ECOWAS helped Nigeria to consolidate its status as regional hegemon by indicating to neighboring countries that they would benefit from Nigeria's oil wealth and from access to its large and lucrative market. ${ }^{23}$ For example, the Community's goal of promoting the free movement of workers could enable desperately poor West Africans to move to a country where jobs and resources were more plentiful. ${ }^{24}$ Nigeria's financial backing was also important. In 1975, import and export taxes ranged from 15 to 50 percent of national revenues. ${ }^{25}$ Governments envisioned that ECOWAS would replace these tax proceeds with a Fund for Cooperation, Compensation and Development. All member states were required to contribute to the fund, but in proportion to each country's gross domestic product and per capita income. Nigerian largesse thus provided the bulk of the Community revenue to replace domestic trade taxes. ${ }^{26}$ It also provided extra funds to support the activities of Community institutions. ${ }^{27}$

Notwithstanding this planned reduction in trade taxes, ECOWAS did not endorse a free market philosophy. To the contrary, its policies reflected the then widely held view that industrialized countries preyed on the economic weaknesses of the developing world. The remedy for this dependency, according to this view, was to build local industrial capacity and an export

${ }^{18}$ E.g., ASANTE, supra note 16, at 48; Julius Emeka Okolo, The Development and Structure of ECOWAS, in WEST AFriCAN REGIONAL COOPERATION AND DEVElopMENT 19, 42 (Julius Emeka Okolo \& Stephen Wright eds., 1990).

${ }^{19}$ Mary E. Burfisher \& Margaret B. Missiaen, Intraregional Trade in West Africa, in WEST AFRICAN REGIONAL COOPERATION AND DEVELOPMENT, supra note 18, at 185-213; Phoebe Kornfeld, ECOWAS, The First Decade: Towards Collective Self-Reliance, or Maintenance of the Status Quo?, in WEST AFRICAN REGIONAL COOPERATION AND DEVELOPMENT, supra note 18, at 87, 91 (noting that intraregional trade averaged between 2.8 percent and 4.1 percent of the member states' total trade volume during the first ten years of ECOWAS). These trade volumes have remained stable since the 1970s. IBRAHIM A. GAMBARI, POLITICAL AND COMPARATIVE DIMENSIONS OF REGIONAL INTEGRATION: THE CASE OF ECOWAS 40-41 (1991).

${ }^{20}$ E.g., Agu, supra note 17, at 455; Kofi Oteng Kufuor, Sub-state Protectionism in Ghana, 18 AFr. J. INT'L \& COMP. L. 78, 80-81 (2010).

${ }^{21}$ E.g., Olayiwola Abegunrin, Africa in Global Politics in the Twenty-First Century: A PAN-AFRICAN PERSPECTIVE 42 (2009) (explaining that "Nigeria has become the big brother (Super power) of West Africa”).

${ }^{22}$ Okolo, supra note 18 , at 42.

${ }^{23}$ GAMBARI, supra note 19, at 18; KUFUOR, supra note 12, at 22; Olatunde Ojo, Nigeria and the Formation of ECOWAS, 34 INT'L ORG. 571, 584 (1980).

${ }^{24}$ Julius Emeka Okolo, Free Movement of Persons in ECOWAS and Nigeria's Expulsion of Illegal Aliens, 40 WORLD TODAY 428, 431 (1984).

${ }^{25}$ GAMBARI, supra note 19, at 42; Okolo, supra note 18, at 49 n.43.

${ }^{26}$ Okolo, supra note 18 , at 32 (explaining that Nigeria provided nearly one-third of the contributions to the Community fund).

${ }^{27}$ GAMBARI, supra note 19, at 58. 
sector to replace reliance on foreign imports. ${ }^{28}$ Nigeria, in particular, favored a region-wide effort to build indigenous industries. ${ }^{29}$ The Francophone countries, however, were heavily dependent on investment from France, and foreign investors were primarily interested in gaining access to regional markets. Voting as a bloc, the Francophone members of ECOWAS prevented the adoption of Community rules of origin. Anglophone members reacted, in turn, by opposing free-trade rules that would have given French producers open access to their markets. ${ }^{30}$ The net result of these intraregional tensions was a stalemate within ECOWAS and rampant noncompliance with Community rules. ${ }^{31}$ Not surprisingly, assessments of the on-the-ground impact of the first phase of West African integration were overwhelmingly negative. ${ }^{32}$

\section{The Rise of Regional Security, Good Governance, and Human Rights in ECOWAS}

The 1980s was a period of economic turmoil and political conflict in West Africa. Early in the decade, the collapse of world oil prices and the mismanagement of oil revenues led Nigeria to focus on domestic priorities and deemphasize its commitment to ECOWAS. ${ }^{33}$ A further low point followed in 1983 when Nigeria expelled hundreds of thousands of "illegal" workers from other member states. Mass expulsions had occurred before in West Africa. But the 1975 ECOWAS Treaty and its free-movement protocols professed a commitment to a different and more open migration policy. ${ }^{34}$ Nigeria's expulsions increased employment opportunities for domestic workers and thus were politically popular at home. But they were widely viewed as flouting the spirit, if not the letter, of ECOWAS free-movement rules. ${ }^{35}$

The end of the Cold War had a significant impact on the Community. West African countries began to liberalize their economies as a condition of receiving loans from the World Bank, gaining access to European markets and, eventually, joining the World Trade Organization. These powerful external forces made the embrace of regional economic integration newly attractive. $^{36}$

The revival and expansion of ECOWAS was embodied in a new agreement, the 1993 Treaty, ${ }^{37}$ that replaced the 1975 founding charter. The 1993 Treaty recommitted West African governments to economic integration, setting timetables for establishing the customs and monetary unions, and further reducing barriers to intraregional trade. The member states also endorsed structural changes to achieve these goals. They authorized certain ECOWAS decisions

${ }^{28}$ ASANTE, supra note 16, at 42-43; GAMBARI, supra note 19, at 42-43; KUFUOR, supra note 12, at xii.

${ }^{29}$ KUFUOR, supra note 12 , at 27.

$30 \mathrm{Id}$. at $26-29$.

${ }^{31}$ GAMBARI, supra note 19, at 44; Jebuni, supra note 13, at 495.

${ }^{32}$ E.g., KUFUOR, supra note 12, at 19-34; Jebuni, supra note 13, at 490-99.

33 GAMBARI, supra note 19, at 47.

${ }^{34}$ E.g., Protocol A/P.1/5/79 Relating to Free Movement of Persons, Residence and Establishment, Art. 2.1, May 29, 1979, at http://www.comm.ecowas.int/sec/index.php?id=protocole\&lang=en; see also ASANTE, supra note 16, at 151 ("As far as ECOWAS is concerned, the movement of labor is part of the philosophy of its founders....”).

${ }^{35}$ Okolo, supra note 24, at 432-33; GAMBARI, supra note 19, at 47.

${ }^{36}$ KUFUOR, supra note 12 , at 42-43.

${ }^{37}$ Revised Treaty of the Economic Community of West African States, July 24, 1993, 35 ILM 660 [hereinafter 1993 Treaty]. 
to be adopted by a vote of two-thirds of the member states, made those decisions expressly binding on the member states, created new ECOWAS institutions such as the Community Parliament, ${ }^{38}$ and increased the power of existing bodies. ${ }^{39}$

Although the 1993 Treaty reads primarily as a recommitment to economic integration, in practice the second phase of ECOWAS came to be dominated by security, good governance, and human rights concerns. Early on, the Community had acquired a role in promoting regional security. A 1978 Protocol on Non-aggression ${ }^{40}$ and a 1981 Protocol Relating to Mutual Assistance on Defense ${ }^{41}$ provided the legal basis for these tasks. These initiatives were primarily aimed at deflecting foreign interventions, but they also established a Defense Council and Defense Commission that could more broadly supervise regional security initiatives. ${ }^{42}$

The Liberian civil war marked a turning point. Although there had been previous conflicts in the region, the civil war in that country led Anglophone member states to establish the Economic Community of West African States Monitoring Group (ECOMOG). ${ }^{43}$ What began as a monitoring and mediation effort as part of the Protocol on Mutual Assistance and Defense became a full-fledged military intervention. ${ }^{44}$ Most observers credited the intervention with preventing the spread of violence and restoring a semblance of stability in Liberia. But the intervention also generated credible and serious allegations of human rights abuses by ECOMOG forces. ${ }^{45}$ Subsequent military missions to quell civil wars and armed conflicts in Sierra Leone in 1997, Guinea Bissau in 1999, and Côte d'Ivoire and Liberia in 2003 increased the political salience of security and humanitarian activities in ECOWAS and led to the adoption in 1999 of a Protocol Relating to the Mechanism for Conflict Prevention, Management, Resolution, Peace-Keeping and Security (1999 Conflict Prevention Protocol) that underscored the importance of protecting human rights and put regional intervention on a firmer legal footing. ${ }^{46}$ These expansions of the Community's powers contributed to a growing mobilization around

\footnotetext{
${ }^{38}$ Protocol A/P.2/8/94 Relating to the Community Parliament, Aug. 6, 1994, at http://www.parl.ecowas.int/ doc/protocols_eng.pdf.

${ }^{39}$ For an overview of the 1993 Treaty, see KUFUOR, supra note 12, at 35-68; Iwa Akinrinsola, Legal and Institutional Requirements for West African Economic Integration, 10 L. \& BUS. REV. AM. 493, 504-08 (2004).

${ }^{40}$ Apr. 22, 1978, in COMPENDIUM OF ECOWAS PEACE \& SECURITY DECISIONS 57 (Emmanuel Kwesi Aning, Emma Birikorang \& Thomas Jaye eds., 2010), at http://www.kaiptc.org/getattachment/MediaRoom/News/Compendium-of-ECOWAS-Peace-and-Security-Decisions/Compendium-of-ECOWAS-Peace-andSecurity-Decisions.pdf.aspx.

${ }^{41}$ A/SP3/5/81, May 29, 1981, in COMPENDIUM OF ECOWAS PEACE \& SECURITY DECISIONS, supra note 40, at 61 .

42 See Peter Jenkins, The Economic Community of West African States and the Regional Use of Force, 32 DENV. J. INT'L L. \& POL'Y 333, 335-36 (2008).

${ }^{43}$ JOHN M. KABIA, HuMANITARIAN INTERVENTION AND CONFLICT RESOLUTION IN WEST AFriCA 57-160 (2009); see also ADEKEYE ADEBAJO \& ISMAIL O. D. RASHID, WEST AFRICA's SECURITY CHALLENGES: BUILDING PEACE IN A TROUBLED REGION (2004).

${ }^{44}$ See Jenkins, supra note 42, at 342-44.

45 E.g., Peter Arthur, ECOWAS and Regional Peacekeeping Integration in West Africa: Lessons for the Future, 57 AFRICA TODAY 2, 16 (2010); KABIA, supra note 43, at 86-87.

${ }^{46}$ Protocol Relating to the Mechanism for Conflict Prevention, Management, Resolution, Peace-Keeping and Security, Art. 2, Dec. 10, 1999 (declaring as a "fundamental principles" the "protection of fundamental human rights and freedoms and the rules of international humanitarian laws"), in COMPENDIUM OF ECOWAS PEACE \& SECURITY DECISIONS, supra note 40, at 61; see also Isaac Terwase Sampson, The Responsibility to Protect and ECOWAS Mechanisms on Peace and Security: Assessing Their Convergence and Divergence on Intervention, 16 J. CONFLICT \& SECURITY L. 507, 515-18 (2011).
} 
human rights in West Africa, and as we explain in part IV, opened the door for the transformation of the ECOWAS Court into an international human rights court.

As part of the 1993 overhaul, member states agreed to broaden public participation in ECOWAS by expanding access for civil society groups. National NGOs were precluded from participating in Community policymaking, but regional civil society groups could be accredited to observe public meetings, make presentations, and circulate documents. ${ }^{47}$ These institutional reforms created an incentive for civil society groups to mobilize within ECOWAS and to create regional advocacy bodies. In 2001, NGOs formed the West African Human Rights Forum, an umbrella organization that gained accreditation from ECOWAS and attempted to influence Community policymaking. ${ }^{48}$ These opportunities for regional mobilization provided an avenue in 2004 for human rights groups to contribute to proposals to expand the Court's jurisdiction. NGO access was also important five years later when the Gambian government, unhappy with Court's rulings against it, proposed curbing its newly acquired authority to hear human rights cases.

Another expansion of ECOWAS competence was an important precursor for the ECOWAS Court's transformation. In 2001, the member states adopted a Protocol on Democracy and Good Governance (2001 Good Governance Protocol) to deter military coups and unconstitutional changes of government. ${ }^{49}$ The Protocol wove multiple references to human rights into the fabric of an ambitious regional effort to promote democracy, accountability, transparency, and the rule of law. ${ }^{50}$ It also included a clause promising that the jurisdiction of the ECOWAS Court "shall be reviewed so as to give the Court the power to hear, inter-alia, cases relating to violations of human rights, after all attempts to resolve the matter at the national level have failed." 51 These developments gave human rights advocates a legal foothold when they later lobbied to give the Court a human rights jurisdiction.

\section{The Decision to Create a Community Court of Justice for Interstate Disputes}

We now situate the creation of the ECOWAS Court within these wider regional developments. ECOWAS's founders envisioned a tribunal to "ensure the observance of law and justice in the interpretation of the provisions of [the 1975] Treaty" and to "settl[e] such disputes as may be referred to it" by the member states. ${ }^{52}$ But the tribunal was never created during the founding period for two reasons. The first relates to Nigeria's regional hegemony. ECOWAS

\footnotetext{
${ }^{47}$ Decision A/DEC.9/8/94 Establishing Regulations for the Grant to Non-governmental Organisations (NGOs) the Status of Observer Within the Institutions of the Community, Aug. 6, 1994, discussed in KUFUOR, supra note 12 , at 49-50.

48 Telephone interview with Human Rights Advocate B (Feb. 3, 2011).

49 Protocol A/SP1/12/01 on Democracy and Good Governance Supplementary to the Protocol Relating to the Mechanism for Conflict Prevention, Management, Resolution, Peacekeeping and Security, Dec. 21, 2001 [hereinafter 2001 Good Governance Protocol], at http://www.comm.ecowas.int/sec/en/protocoles/Protocol \%20on\%20good-governance-and-democracy-rev-5EN.pdf. For a recent assessment, see Frederick Cowell, The Impact of the ECOWAS Protocol on Good Governance and Democracy, 19 AFR. J. INT'L AND COMP. L. 331 (2011).

50 See Solomon T. Ebobrah, Legitimacy and Feasibility of Human Rights Realisation Through Regional Economic Communities in Africa: The Case of the Economic Community of West African States 100-02 (2009) (LLD dissertation, University of Pretoria), at http://upetd.up.ac.za/thesis/available/etd-02102010-085034/ unrestricted/00front.pdf.

512001 Good Governance Protocol, supra note 49, Art. 39.

${ }^{52}$ Treaty of the Economic Community of West African States, supra note 11, Arts. 11, 56.
} 
institutions have always depended on the largesse of Nigerian oil revenues, and Nigeria was reluctant to embrace "an organ that could circumscribe its role as the regional hegemon." 53 The second relates to the weak legal underpinnings for a Community court. ECOWAS protocols did not have direct effect in national law, ${ }^{54}$ and as noted above, most were rarely implemented. In an environment in which member states neither implemented nor complied with Community rules, a supranational tribunal would have been "largely redundant." 55

The decision to create the ECOWAS Court was part of the broader recommitment to regional integration in the early 1990 s. $^{56}$ As governments prepared to relaunch the Community, national interior ministers submitted to the member states a proposal to create a court. The ministers wanted a court to resolve disputes relating to key ECOWAS instruments and programs, including the Protocol on Free Movement of Persons, Residence and Establishment, ${ }^{57}$ the Trade Liberalisation Scheme, the Agricultural Cooperation Programme, and the Protocol on Community Enterprises. ${ }^{58}$ The renewed governmental support for a court in the early 1990 s reflected a growing sense that deeper regional integration required a judicial body to resolve disputes and interpret legal rules. ${ }^{59}$

A 1991 Community protocol (1991 Protocol) created an international court to carry out these tasks. ${ }^{60}$ The Protocol authorized the ECOWAS Court to adjudicate two types of cases relating to "the interpretation and application" of ECOWAS legal instruments: (1) "disputes referred . . by Member States or the Authority, when such disputes arise between the Member States or between one or more Member States and the Institutions of the Community," and (2) proceedings instituted by a member state "on behalf of its nationals . . against another Member State or Institution of the Community . . . after attempts to settle the dispute amicably have failed." 61

The 1991 Protocol also included what, in retrospect, was a portentous decision: it established the ECOWAS Court as a permanent institution. At the time, member states were uncertain what kind of judicial body the Community needed. Officials in the ECOWAS Legal Affairs Directorate favored an ad hoc tribunal, which would be less costly and appropriate for the small number of interstate disputes capable of judicial resolution. Member states, however, were

${ }^{53}$ KUFUOR, supra note 12, at 44.

${ }^{54}$ Akinrinsola, supra note 39, at 503.

${ }^{55} \mathrm{Id}$. at 504.

${ }^{56}$ Final CEP Report, supra note 14, at 19-21; LADAN, supra note 16, at 2.

57 See supra note 34.

58 Protocol A/P1/11/84 Relating to Community Enterprises, Nov. 23, 1984; see ECOWAS Ministers of Justice Meet in Lagos, 2 CONTACT MAG., no. 3, 1990, at 15 (on file with authors) (reporting statements by ECOWAS Deputy Executive Secretary Adelino Queta).

${ }^{59}$ Akinrinsola, supra note 39, at 507-08; Kofi Oteng Kufuor, Securing Compliance with the Judgements of the ECOWAS Court of Justice, 8 AFR. J. INT'L \& COMP. L. 1, 4 (1996).

${ }^{60}$ Protocol A/P.1/7/91 on the Community Court of Justice, Arts. 3(1), 4(1), July 6, 1991 [hereinafter 1991 Protocol], provided for a court comprising seven independent judges, each of whom served for a five-year term renewable once. The judges were appointed "by the Authority and selected from a list of persons nominated by Member States" who had qualifications similar to those associated with other international courts and tribunals. Id., Art. 3(1), (4).

${ }^{61}$ Id., Art. 9(2), (3). The 1991 Protocol also authorized the ECOWAS Court to issue advisory opinions concerning the Treaty "at the request of the Authority, Council, one or more Member States, or the Executive Secretary and any other institution of the Community." Id., Art. 10(1). 
more focused on expanding ECOWAS competences and creating new Community institutions. In this heady atmosphere of supranational expansion, "the Authority said, 'let's have a court." "62

The 1991 Protocol did not, however, include another design feature favored by the supporters of supranational integration - a provision granting private litigants access to the Court. As part of a review process leading to the restructuring of ECOWAS in the 1993 Treaty, the Authority appointed a Committee of Eminent Persons, chaired by General Yakubu Gowon of Nigeria, to assess the shortcomings of the founding period. The committee's reports to the Authority stressed the "importance of [private actors and] interest groups in the integration process," both in the interests of democratic legitimacy and because "some of the Community decisions have to be implemented either directly or indirectly" by these actors. ${ }^{63}$ The committee also endorsed granting individuals, firms, and interest groups access to the Court:

Where, however, a Community citizen alleges a breach or denial of a right conferred on him by a Community legislation, a Treaty provision or a protocol, it should be possible for him to seek redress in the national Court or the Community Court of Justice. . . . This proposal would also require amendment to Article 9 of the [1991] Protocol . . . . Under the present provisions, nationals do not have a locus standi in the Court of Justice. Member States have to act on their behalf, and even so, only in cases relating to the interpretation and application of the provisions of the Treaty, "after attempts to settle the dispute amicably have failed." 64

We do not know why the member states did not act on this proposal. Perhaps it was politically expedient not to deviate from a design template that the ECOWAS Authority had previously vetted and approved. Or perhaps the member states, especially Nigeria, did not actually want a tribunal with design features that would enhance the supranational aspects of ECOWAS or constrain their freedom of action. ${ }^{65}$

The delay in establishing the ECOWAS Court as a working court is consistent with the latter explanation. The 1991 Protocol did not enter into force until November $1996 .{ }^{66}$ Even then, the Court existed only on paper. The situation changed in 1999 when Olusegun Obasanjo assumed the presidency of Nigeria. Obasanjo increased the country's international profile, in part by reviving its leadership of the Community. ${ }^{67} \mathrm{~W}$ ith the region's economic powerhouse

${ }^{62}$ Interview with ECOWAS Legal Affairs Directorate A, in Abuja, Nigeria (Mar. 7, 2011).

${ }^{63}$ Committee of Eminent Persons for the Review of the ECOWAS Treaty, Draft Report 28, ECOWAS Doc. ECW/CEP/TREV/VI/2 (June 1992) [hereinafter Draft CEP Report] (on file with authors); Final CEP Report, supra note 14, at 23-24 (containing a similar statement).

${ }^{64}$ Final CEP Report, supra note 14, at 20-21; Draft CEP Report, supra note 63, at 20. Elsewhere, the final report suggests that the committee's recommendation was for private litigants to have direct access to the ECOWAS Court rather than access via national courts. Final CEP Report, supra note 14 , at 8.

${ }^{65}$ Several scholars have argued that private access contributes to the effectiveness of international courts. See, e.g., Robert O. Keohane, Andrew Moravcsik \& Anne-Marie Slaughter, Legalized Dispute Resolution: Interstate and Transnational, 54 INT'L ORG. 457, 472-76 (2000); Helfer \& Slaughter, supra note 8, at 287-90. Other scholars have applied this insight to subregional courts in Africa. See, e.g., RICHARD FRIMPONG OPPONG, LEGAL ASPECTS OF ECONOMIC INTEGRATION IN AFRICA 119 (2011).

${ }^{66}$ The Protocol was provisionally effective from the date of its conclusion in 1991, but it did not enter into force "definitively" until it had been ratified by seven member states. 1991 Protocol, supra note 60, Art. 34.

${ }^{67}$ E.g., JOHN IlifFe, OBASANJO, NigERIA AND THE WORLD 129, 217-24 (2011); J. Shola Omotola, From Importer to Exporter: The Changing Role of Nigeria in Promoting Democratic Values in Africa, in AFRICAN POLITICS: BEYOND THE THIRD WAVE OF DEMOCRATISATION 31, 39 (Joelien Pretorius ed., 2008). 
once again favoring integration, ECOWAS institutions - including the Court- became a priority. In December 2000, the member states appointed the first seven judges, who were sworn into office on January 31, 2001. The judges picked Hansine Donli as the Court's president. Donli was a natural choice to lead the Court. As a Nigerian with a network of contacts in the country, it would be easier for her to arrange for the infrastructure and administrative support that the judges required. ${ }^{68}$

Among the Court's initial tasks was finding courtrooms and offices for the judges, the chief registrar, and their staffs. ${ }^{69}$ The judges secured the construction of a new building in Abuja, paid for by Nigeria. They next began outreach efforts to attract cases. ${ }^{70}$ According to Donli, member states were largely unaware of "the need to seek [the Court's] advice with respect [to] the different problems they will be facing, arising from interpretation of the Treaty and Protocols." ${ }^{71}$ Notwithstanding these outreach efforts, however, the ECOWAS Court remained idle for nearly three years after opening its doors for business.

\section{EXPANDING THE JURISDICTION AND ACCESS RULES OF THE ECOWAS COURT}

The member states created the ECOWAS Court to adjudicate interstate economic disputes. But in the wake of the humanitarian interventions of the 1990s, and as human rights NGOs became more active in regional policymaking - an involvement made possible by the Community's new openness to civil society-the NGOs saw an opportunity to redeploy an existing institution to promote their objectives. They focused on a provision in the 2001 Good Governance Protocol that suggested that the not-yet-operational Court might one day hear "cases relating to violations of human rights, after all attempts to resolve the matter at the national level have failed." ${ }^{\prime 2}$ In 2001, such a possibility seemed remote. In this part we explain how advocates transformed that vague promise into a reality.

The opportunity for change presented itself following the Court's first decision-Afolabiv. Nigeria - a case challenging blatant noncompliance with ECOWAS free-movement rules. ${ }^{73}$ We first review the Court's dismissal of the case and then explain how ECOWAS judges, civil society groups, and ECOWAS officials lobbied the member states to expand the Court's jurisdiction. We then consider how these actors created an international human rights court with design features different from other human rights tribunals.

${ }^{68}$ Interview with judges at the headquarters of the ECOWAS Community Court of Justice, in Abuja, Nigeria (Mar. 11, 2011); Adelanwa Bamgboye, Nigeria: Some Judges Are Strong Even at 80_Hansine Donli, DAILY TRUST (Nigeria) (Sept. 28, 2010), at http://allafrica.com/stories/201009280476.html. Although the news archive at AllAfrica.com requires a subscription, each of the links to that archive leads to a web page with the first few sentences of the article, information about its publication, and a link to the full article. All sources cited from AllAfrica.com are also on file with authors.

${ }^{69}$ The ECOWAS Court was initially located in Lagos, Nigeria. It moved to its permanent headquarters in the capital of Abuja after Nigeria was designated in 2002 as the host country of the Court. Adewale Banjo, The ECOWAS Court and the Politics of Access to Justice in West Africa, 32 AFR. DEV. 69, 77 (2007).

${ }^{70}$ Interview with judges at the headquarters of the ECOWAS Community Court of Justice, supra note 68; see also Lillian Okenwa, Law Personality: 'ECOWAS CourtJurisdiction Will Be Expanded, 'ALLAFRICA.COM (Sept. 21, 2004) (describing outreach efforts by ECOWAS judges), at http://allafrica.com/stories/200409210061.html.

${ }^{71}$ Banjo, supra note 69, at 77.

722001 Good Governance Protocol, supra note 49, Art. 39.

${ }^{73}$ Afolabi v. Nigeria, Case No. ECW/CCJ/APP/01/03, Judgment (Apr. 27, 2004), reprinted in 2004-2009 COMMUNITY COURT OF JUSTICE, ECOWAS LAW REPORT 1 (2011). 


\section{The Afolabi Case: Justice Denied for Private Litigants}

Olajide Afolabi was a Nigerian trader who had entered into a contract to purchase goods in Benin. Afolabi could not complete the transaction because Nigeria unilaterally closed the border between the two countries. He filed suit with the ECOWAS Court, alleging that the border closure violated the right to free movement of persons and goods. ${ }^{74}$

Nigeria challenged the Court's jurisdiction and Afolabi's standing, arguing that the 1991 Protocol did not authorize private parties to litigate before the Court. Afolabi countered by invoking a Protocol provision stating that a "Member State may, on behalf of its nationals, institute proceedings against another member State." 75 He asserted that the word "may" permits states to raise such cases but does not preclude the Court from receiving complaints from individuals. ${ }^{76}$ Afolabi also argued that when a private party sues his own country, that nation "cannot represent the party because the Member State cannot be both the plaintiff and the defender."77 Finally, Afolabi invoked "the principles of equity"78 in the 1991 Protocol to support an expansive interpretation of the Court's jurisdiction. ${ }^{79}$

The Court rejected each of these arguments and dismissed the suit. The judges acknowledged that Afolabi's complaint raised "a serious claim touching on free movement and free movement of goods," 80 but they reasoned that an ECOWAS legal instrument must expressly grant the Court jurisdiction. Article 9 of the 1991 Protocol is "plain" and "unambiguous" on this issue: only states can institute proceedings on behalf of their nationals. ${ }^{81}$ The Protocol must therefore be applied as written, even if the result — insulating states against suits by their own nationals alleging violations of ECOWAS rules—seems "repugnant," "absurd[]," or "harsh." 82

The ECOWAS Court also rejected Afolabi's broad interpretation of the word "equity" in the 1991 Protocol, comparing it to a similar provision in the Treaty Establishing the European Community. ${ }^{83}$ According to the Court, "activist[] judges" on the European Court of Justice had applied this provision to "define the role of the [European] court very broadly," "to extend its review on jurisdiction to cover bodies which were not listed in the Treaty," and "to fill in gaps in treaties." ${ }^{44}$ The ECOWAS judges candidly declared that, because "some of the [ECJ's] decisions [have] attracted criticisms," "[w]e . . do not want to tow on the same line." 85

The Afolabi case was a paradigmatic illustration of the serious physical and legal barriers confronting the region's importers and exporters. Like the ECJ before it, the ECOWAS Court

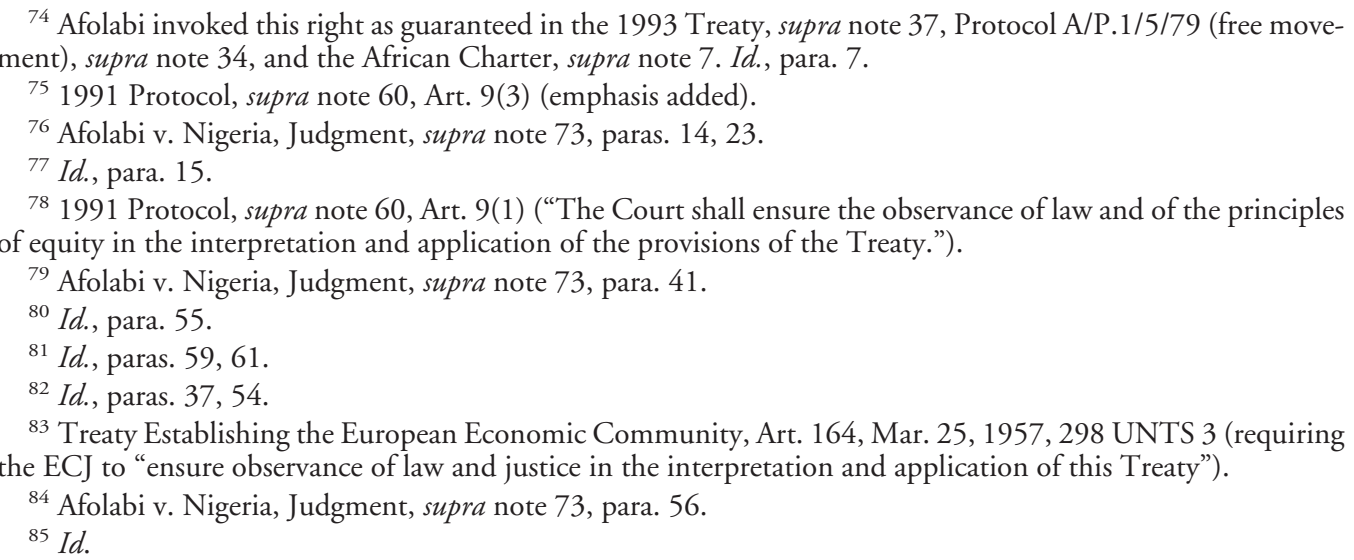


could have adopted a purposive interpretation of Community economic rules to enable private traders to challenge those barriers. Instead, the judges responded with restraint. They strictly interpreted the 1991 Protocol and concluded that only ECOWAS member states could authorize the Court to review complaints from private actors.

\section{The Coordinated Campaign by Nonstate Actors to Redesign the ECOWAS Court, and the Surprising Absence of Member State Opposition}

The dismissal of the Afolabi suit exposed a basic flaw in the Court's architecture: governments had little incentive to challenge barriers to regional integration, and private traders had no judicial mechanism for doing so. Responding to this flaw, ECOWAS judges, NGOs, and Community officials launched a campaign to expand the Court's jurisdiction. The campaign succeeded, but the institutional reforms did not address the unsatisfactory outcome in Afolabi. Instead, the changes gave the ECOWAS Court a capacious human rights mandate. In this section, we describe the coordinated campaign by ECOWAS judges, NGOs, and Community officials to lobby for giving the Court jurisdiction over human rights cases. We also explore the surprising lack of member state opposition to the campaign. In part IV, we return to these events to explain why court reform omitted private litigant access in economic cases.

ECOWAS judges had long recognized the problems that the Afolabi case illustrated. As one judge explained in an interview: "Individuals started to come and asked us if they had access to the Court. They were surprised because ECOWAS has Protocols that affected them-such as free movement of people and goods - and they didn't understand how the Protocols were supposed to be effective." The judges were discussing how to address the situation when Afolabi filed his complaint in October 2003. The case's sympathetic facts "assisted us in making a proposal" to expand the Court's jurisdiction, relying on a clause in the 1991 Protocol that invites such proposals. ${ }^{86}$

In contrast to the narrow, formalist analysis of the Afolabi decision, the judges raised expansive policy arguments outside the courtroom to lobby for an overhaul of the 1991 Protocol. On the same day that the Court released the Afolabi judgment, it also issued a press release urging governments "to enable individuals to bring actions before the court as there are cases member states cannot bring on behalf of [their] nationals." ${ }^{87}$ The Court also published a booklet that summarized the legal arguments of parties in Afolabi and the judgment dismissing the suit. The judges distributed the booklet widely to show that they had finally issued a decision and to highlight the flaws in the ECOWAS legal system. ${ }^{88}$ During the next several months, in meetings with lawyers, civil society groups, and government officials, and in statements to the

\footnotetext{
${ }^{86}$ Interview with judges at the headquarters of the ECOWAS Community Court of Justice, supra note 68; 1991 Protocol, supra note 60, Art. 33(1) (providing that "the President of the Court may . . . submit proposals for amendments of this Protocol").

${ }^{87}$ Lillian Okenwa, ECOWAS Court Not Open to Individual Litigants, THIS DAY (Nigeria) (Apr. 28, 2004) (on file with authors); see also ECOWAS Throws Out Suit Against Nigeria over Land Border Closure with Benin, VANGUARD (Nigeria) (Apr. 28, 2004), 2004 WLNR 7109799.

${ }^{88}$ During interviews at the Federal Ministry of Trade and Commerce of Nigeria, March 8, 2011, in Abuja, Nigeria, we were shown the booklet and discussed how it had been distributed.
} 
news media, ${ }^{89}$ the judges continued to publicize the need to provide access for private litigants. $^{90}$

Regional bar associations and human rights groups joined the judges' campaign. The focus on human rights issues in ECOWAS — which, as part I explained, began with the abuses linked to ECOMOG's humanitarian interventions_-expanded during the ensuing decade as civil society groups capitalized on the shift to more democratic governments, the rebranding of ECOWAS as a "people-centered" institution, and the enhanced access rules for transnational NGOs. ${ }^{91}$

Shortly after the Court dismissed the Afolabi case, human rights groups seized the opportunity for court reform. ${ }^{92}$ Leaders of the West African Bar Association met with ECOWAS judges and staff to press the case for "a Court that could address human rights issues." 93 With the judges' support, bar association attorneys consulted with other NGOs and ECOWAS officials to develop a proposal to revise the Court's jurisdiction. The key stakeholders met in Dakar, Senegal, in October 2004 at a consultative forum organized by the Open Society Initiative for West Africa. ${ }^{94}$ The forum issued a declaration calling for the

${ }^{89}$ E.g., Lillian Okenwa, Broaden ECOWAS Court's Jurisdiction, THIS DAY (Nigeria) (Sept. 2, 2004), at http://allafrica.com/stories/200409020666.html; Justice Aminata Malle Sanogo, Practice and Procedure in ECOWAS Court, paper presented at the 2007 Annual General Conference of the Nigerian Bar Association at Ilorin, Kwara State, Nigeria (Aug. 26-31, 2007), quoted in A. O. Enabulele, Reflections on the ECOWAS Community Court Protocol and the Constitutions of Member States, 12 INT'L COMMUNITY L. REV. 111, 117 (2010).

90 The judges appear to have favored giving private litigants access to the Court in both economic and human rights cases:

[T] he right of access to the Court is the keystone in the development of the Community law. The promotion and protection of human rights and fundamental freedoms of Community Citizens cannot be ensured, if right of direct access to the Community Court of Justice is not guaranteed. A cardinal objective of ECOWAS is the formation of an economic union and a common market. . . . [T] his scheme and the intended benefits cannot be realized, unless individuals, consumers, manufacturers and corporate bodies that are the prime movers in commercial transactions have direct access to the Court of Justice.

ECOWAS: Court Procedure and the Application of Protocols 10-12 (n.d.), at http://www.crin.org/docs/ecowas procedure.doc. Circumstantial evidence suggests that the Court prepared this document. Specifically, in press interviews ECOWAS judges echoed similar themes. See, e.g., Lillian Okenwa, ECOWAS Court: Individuals to Have Access, THIS DAY (Nigeria) (Feb. 9, 2005), at http://allafrica.com/stories/200502090527.html. In part IV, we discuss why access for private litigants alleging violations of ECOWAS economic rules was dropped from the court reform agenda.

${ }^{91}$ Telephone interview with Human Rights Advocate A (Jan. 11, 2011); Telephone interview with Human Rights Advocate B, supra note 48; Interview with Human Rights Advocate F, in Abuja, Nigeria (Mar. 7, 2011); Interview with Human Rights Advocate H, in Abuja, Nigeria (Mar. 10, 2011). In 2002, Mohammed Ibn Chambas, ECOWAS's executive secretary from 2002 to 2006, committed to making the Community a "peoplecentered" institution and expanding access to civil society and the public. Interview with Mohamed Ibn Chambas, Executive Secretary of ECOWAS, UN INTEGRATED REGIONAL INFORMATION NETWORK (Mar. 12, 2002), at http://www.irinnews.org/report/30701/west-africa-irin-interview-with-mohamed-ibn-chambasexecutive-secretary-of-ecowas.

${ }^{92}$ Interview with Human Rights Advocate C, in Abuja, Nigeria (Mar. 9, 2011); Telephone interview with Human Rights Advocate B, supra note 48.

${ }^{93}$ Interview with Human Rights Advocate C, supra note 92; see also Femi Falana, The Community Court of Justice, ECOWAS and the Experiences of Other Regional Courts, in COMPENDIUM OF THE INTERNATIONAL CONFERENCE

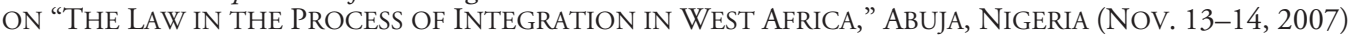
143, 145 (after the Afolabi judgment, the "West African Bar Association collaborated with the Court in the campaign" to give private actors direct access to the ECOWAS Court "for the enforcement of their human rights").

${ }^{94}$ The Consultative Forum on Protecting the Rights of ECOWAS Citizens Through the ECOWAS Court of Justice was held in Dakar, Senegal on October 18-20, 2004. See http://aros.trustafrica.org/index.php/ECOWAS _Community_Court_of_Justice. 
urgent adoption of a protocol to give individuals direct access to the Court in human rights cases. $^{95}$

At this stage, officials in the ECOWAS Executive Secretariat became key players. The secretariat had long supported making ECOWAS more relevant to civil society and adding a human rights mandate to Community legal texts and institutions. ${ }^{96}$ Its officials were also frustrated by the Court's budgetary needs. The Court is a permanent judicial body. But with no cases on its docket, the Court was, in the words of one official, a "huge body with nothing to do." 97 The secretariat wanted to give the judges and staff enough work to justify the large expenditure of Community resources. ${ }^{98}$

The secretariat's backing greatly increased the likelihood that the member states would approve the protocol advocated by ECOWAS judges and NGOs. We asked officials in the Legal Affairs Directorate how national political leaders viewed the court reform proposal. "They trusted us" was the response:

When we draft [legal] texts, we consult a lot. We write memoranda that explain why we are making the proposal. We exchange views with the member states. Member states comment on the draft proposals before we convey any draft legislation. We incorporate all of this input before the actual meeting where the proposal is discussed. ${ }^{99}$

Notwithstanding the ECOWAS secretariat's support for the proposal, the absence of government opposition to giving the Court a human rights mandate is striking. We queried numerous stakeholders to probe for such opposition. They all responded that the proposal was approved without much controversy. By all appearances, that is accurate. We found no evidence that individual countries, or member states collectively, attempted to block, stall, or narrow the protocol. Nonetheless, civil society groups recognized that they needed to "mobilize" to secure the protocol's adoption-in particular, by soliciting the support of sympathetic governments. ${ }^{100}$ They met with the president of Senegal (the only nation in West Africa never ruled by a military dictatorship), arguing that a human rights court was "especially needed for countries whose legal and judicial systems are weak." ${ }^{101}$ The president agreed to support the protocol at the next meeting of the ECOWAS Authority. The NGOs also consulted officials from the justice and integration ministries in several countries, and conferred with the staff of the ECOWAS Legal Affairs Directorate, which was preparing the final draft of the protocol. $^{102}$

Barely nine months after the dismissal of the Afolabi case, the coordinated court reform campaign reached a successful conclusion. On January 19, 2005, the member states adopted the

\footnotetext{
${ }^{9}$ Id.; Interview with Human Rights Advocate C, supra note 92; Nneoma Nwogu, Regional Integration as an Instrument of Human Rights: Reconceptualizing ECOWAS, 6 J. HUM. RTS. 345, 352 (2007).

${ }^{96}$ Nwogu, supra note 95, at 350.

${ }^{97}$ Interview with ECOWAS Legal Affairs Directorate A, supra note 62.

${ }^{98}$ Id.; Interview with ECOWAS Legal Affairs Directorate B, in Abuja, Nigeria (Mar. 7, 2011).

${ }^{99}$ Interview with ECOWAS Legal Affairs Directorate B, supra note 98.

${ }^{100}$ Interview with Human Rights Advocate C, supra note 92; Telephone interview with Human Rights Advocate B, supra note 48.

${ }^{101}$ Interview with Human Rights Advocate C, supra note 92.

${ }^{102} I d$.
} 
2005 Protocol by consensus and with immediate provisional effect. ${ }^{103}$ The Protocol markedly expands the ECOWAS Court's authority, most notably by giving the Court a capacious human rights mandate.

\section{The Distinctive Features of the ECOWAS Court's Human Rights Jurisdiction}

The 2005 Protocol's most important clauses appear in two short sentences in articles redefining the ECOWAS Court's jurisdiction and access rules. Article 3 revises Article 9 of the 1991 Protocol and lists each ground of jurisdiction. The fourth paragraph states: "The Court has jurisdiction to determine case[s] of violation of human rights that occur in any Member State." ${ }^{104}$ Article 4, which adds a new Article 10 to the 1991 Protocol, identifies the litigants who have access to the ECOWAS Court. It includes a subparagraph authorizing the Court to receive complaints from "individuals on application for relief for violation of their human rights." ${ }^{105}$ On first impression, these simple provisions appear straightforward. In reality, they mask three design features that collectively gave the ECOWAS Court much broader authority than other human rights tribunals.

Direct access for private litigants. First, the ECOWAS Court is unusual for a new human rights court in granting direct access to private litigants. For the vast majority of cases in the African and American human rights systems (and in the European system prior to 1998), complainants must first submit their allegations to a quasi-judicial commission that screens complaints and issues nonbinding recommendations for those petitions that it deems admissible. Review by a court with the power to issue a legally binding judgment occurs only if a state has voluntarily accepted the court's jurisdiction and if the commission or the state refers the case for a judicial resolution. ${ }^{106}$

This tiered review structure-a commission to vet complaints, optional jurisdiction, and limiting the actors who can refer cases to a court — provides states with multiple layers of political protection. In the African Charter system, for example, private litigants have direct access to the African Court on Human and Peoples' Rights only if the respondent state has ratified the protocol establishing the Court and filed a separate optional declaration allowing private litigants to submit such complaints. To date, only seven of fifty-four African nations-four of them ECOWAS member states- have filed such declarations. ${ }^{107}$

The ECOWAS Court lacks any of these political buffers. ECOWAS judges have repeatedly affirmed that private litigants "have direct access to . . the Court when their human rights are

\footnotetext{
1032005 Protocol, supra note 10, Art. 11 (providing that the protocol "shall enter into force provisionally upon signature by the Heads of State and Government" and "shall definitively enter into force upon the ratification by at least nine (9) signatory States").

${ }^{104}$ Id., Art. 3 (revising Art. 9(4) of the 1991 Protocol).

${ }^{105}$ Id., Art. 4 (inserting Art. 10(d) into the 1991 Protocol). Article 10(d) also provides that applications alleging human rights violations may not be anonymous and many not be made while the same matter is pending before another international court.

106 Thomas Buergenthal, The Evolving International Human Rights System, 100 AJIL 783, 791-801 (2006).

107 Only twenty-six of fifty-four African Charter member states have ratified the African Court Protocol. Seven of these twenty-six states_-Burkina Faso, Côte d'Ivoire, Ghana, Malawi, Mali, Rwanda, and Tanzaniahave filed separate optional declarations giving private litigants direct access the Africa Court. See Côte d'Ivoire Deposits the Declaration Allowing Individuals Direct Access (July 31, 2013), at http://www.african-court.org/ en/index.php/news/latest-news/426-the-republic-of-cote-d-ivoire-deposits-the-declaration-allowing-individualsand-ngos-direct-access-to-the-african-court.
} 
violated."108 The judges have extended access not only to individuals—who are expressly mentioned in the 2005 Protocol—but to NGOs. ${ }^{109}$ They have also rejected attempts by governments to circumvent the direct access provision, rebuffing arguments that human rights are matters essentially within a state's domestic jurisdiction, that ECOWAS treaties and protocols have no domestic effect, and that direct access for NGOs should be denied because litigants have no standing to challenge human rights violations before national courts. $^{110}$

An indeterminate human rights jurisdiction. A second distinctive feature of the Court's design is that no ECOWAS legal instrument prescribes which human rights its judges can adjudicate. The primary role of the European, Inter-American, and African courts is to interpret and apply their respective regional human rights charters. ${ }^{111}$ Their association with these instruments provides a sanctioned source of law and legal authority for their judges. By contrast, ECOWAS judges have no designated human rights charter to apply. By declining to designate a prescribed catalogue of rights, the 2005 Protocol avoided provoking political controversy over which rights the ECOWAS Court could review. The absence such of an enumerated list, however, also presented risks for the Court-namely, that its new human rights jurisdiction could be challenged as an overbroad delegation to interpret expansively this rapidly evolving area of international law. As we later explain, the Court is also open to the charge that it applies human rights instruments that are not legally binding. ${ }^{112}$

ECOWAS judges have viewed the lack of designated human rights norms as an "opportunity to define and delimit the scope and legal parameters of its human rights mandate in its own image." 113 The Court has underscored the primacy of the African human rights system, noting that all ECOWAS member states are parties to the African Charter, which is also referenced in

108 Tidjani v. Nigeria, Case No. ECW/CCJ/APP/01/06, Judgment, para. 22 (July 28, 2007).

${ }^{109}$ E.g., Socio-Economic Rights and Accountability Project v. Nigeria, Case No. ECW/CCJ/APP/08/09, Ruling, paras. 59-61 (Dec. 10, 2010) [hereinafter SERAP Niger Delta Ruling]; Socio-Economic Rights and Accountability Project v. Nigeria, Case No. ECW/CCJ/APP/08/08, Ruling, paras. 33-34 (Oct. 27, 2009), [hereinafter SERAP Basic Education Ruling]. By contrast, the Court has held that "no corporate body can bring a human rights case before this court as a plaintiff as an alleged victim of human rights abuse." Starcrest Investment Ltd. v. Nigeria, Case No. ECW/CCJ/APP/01/08, Judgment, para. 17 (July 8, 2011).

${ }^{110}$ E.g., SERAP Basic Education Ruling, supra note 109, paras. 18-20; Saidykhan v. The Gambia, Case No. ECW/CCJ/APP/11/07, Ruling, para. 39 (June 30, 2009).

${ }^{111}$ Laurence R. Helfer, Forum Shopping for Human Rights, 148 U. PA. L. REV. 285, 301 (1999). For example, the contentious jurisdiction of the Inter-American Court of Human Rights "relates mainly to the application of the [American Convention on Human Rights], but has also been extended to a few other regional human rights treaties." Gerald L. Neuman, Import, Export, and Regional Consent in the Inter-American Court of Human Rights, 19 EUR. J. INT'L L. 101, 102 (2008). The Court's advisory jurisdiction is wider, extending to the interpretation of other human rights treaties ratified by Organization of American States member states. Id. at $102 \&$ n.2. The jurisdiction of the African Court on Human and Peoples' Rights is broader still. It applies principally to the African Charter but also extends to "other relevant Human Rights instrument[s] ratified by the States concerned" (contentious jurisdiction) and "any other relevant human rights instruments" (advisory jurisdiction). Protocol to the African Charter on Human and Peoples' Rights on the Establishment of an African Court on Human and Peoples' Rights, Arts. 3, 4, June 10, 1998, OAU Doc. OAU/LEG/EXP/AFCHPR/PROT (III) (entered into force Jan. 25, 2004).

112 See Ebobrah, supra note 9, at 93; Solomon T. Ebobrah, Critical Issues in the Human Rights Mandate of the ECOWAS Court of Justice, 54 J. AFR. L. 1, 3-7 (2010) [hereinafter Ebobrah, Critical Issues].

113 Tony Anene-Maidoh, The Mandate of a Regional Court: Experiences from ECOWAS Court of Justice, paper presented at the Regional Colloquium on the SADC Tribunal, Johannesburg (Mar. 12-13, 2013) (statement by ECOWAS Court chief registrar). 
the 1993 Treaty. ${ }^{114}$ But ECOWAS judges also regularly apply the Universal Declaration of Human Rights and UN human rights conventions that member states have ratified, ${ }^{115}$ including the International Covenant on Civil and Political Rights, ${ }^{116}$ the International Covenant on Economic, Social and Cultural Rights, ${ }^{117}$ and the UN Convention Against Torture. ${ }^{118}$

The ECOWAS Court also considers a broad array of other sources when interpreting human rights norms. The Court draws inspiration from the 1991 Protocol's directive to "apply, as necessary, the body of laws as contained in Article 38 of the Statute of the International Court of Justice," 119 which, in turn, specifies that treaties, custom, and general principles of law, as well as national judicial decisions and the teachings of highly qualified publicists, are all sources of international law. ${ }^{120}$ The Court has relied on this provision to consult a wide array of binding and hortatory international human rights instruments and national laws. ${ }^{121}$ In Hadijatou Mani Kouraou v. Niger, for example, the judges cited a multiplicity of sources in reaffirming the peremptory norm against slavery, and they endorsed the definition of modern forms of slavery adopted by the International Criminal Tribunal for the Former Yugoslavia. ${ }^{122}$

No requirement to first exhaust domestic remedies. The ECOWAS Court's ability to hear human rights cases is aided by the absence of a requirement to exhaust local remedies. In all other regional and UN human rights petition systems, individuals must first seek relief in national courts, administrative agencies, or other domestic venues. ${ }^{123}$ If a petitioner does not exhaust such remedies — or explain why they are unavailable, ineffective, or insufficient — the international tribunal will dismiss her complaint. ${ }^{124}$

${ }^{114}$ E.g., Alade v. Nigeria, Case No. ECW/CCJ/APP/05/11, Judgment, para. 24 (June 11, 2012); Keita v. Mali, Case No. ECW/CCJ/APP/05/06, Judgment, para. 34 (Mar. 22, 2007).

${ }^{115}$ E.g., Alade v. Nigeria, Judgment, supra note 114, para. 25 (asserting the authority to interpret "UN Conventions ... . acceded to by Member States of ECOWAS").

${ }^{116}$ Dec. 16, 1966, 999 UNTS 171.

117 Dec. 16, 1966, 999 UNTS 3.

${ }^{118}$ Convention Against Torture and Other Cruel, Inhuman or Degrading Treatment or Punishment, Dec. 10, 1984, S. TREATY DOC. NO. 100-20 (1988), 1465 UNTS 113.

1191991 Protocol, supra note 60, Art. 19.

${ }^{120}$ Statute of the International Court of Justice, Art. 38.

${ }^{121}$ E.g., David v. Uwechue, Case No. ECW/CCJ/APP/04/09, Ruling, para. 41 (June 11, 2010) ("As an international court with jurisdiction over human rights violation $[\mathrm{s}$, ] the court cannot disregard the basic principles as well as the practice that guide the adjudication of the disputes on human rights at the international level.").

${ }^{122}$ Hadijatou Mani Koraou v. Niger, Case No. ECW/CCJ/APP/08/07, Judgment, paras. 74-75, 77 (Oct. 27, 2008), unofficial translation available at http://www.refworld.org/pdfid/496b41fa2.pdf.

123 "The rule that local remedies must be exhausted before international proceedings may be instituted is a wellestablished rule of customary international law[.]" Interhandel (Switz. v. U.S.), 1959 ICJ REP. 6, 27 (Mar. 21). Some international agreements - most notably, bilateral investment treaties-intentionally omit an exhaustion requirement. E.g., George K. Foster, Striking a Balance Between Investor Protections and National Sovereignty: The Relevance of Local Remedies in Investment Treaty Arbitration, 49 COLUM. J. TRANSNAT'L L. 201 (2011). For human rights treaties, however, exhaustion is ubiquitous. For example, the African Commission "can only deal with a matter submitted to it after making sure that all local remedies, if they exist, have been exhausted, unless it is obvious to the Commission that the procedure of achieving these remedies would be unduly prolonged." African Charter, supra note 7, Art. 50; see also Office of the United Nations High Commissioner for Human Rights, Human Rights Treaty Bodies - Individual Communications, Procedure for Complaints by Individuals Under the Human Rights Treaties, at http://www2.ohchr.org/english/bodies/petitions/individual.htm.

${ }^{124}$ According to the African Commission, "A remedy is considered available if the petitioner can pursue it without impediment; it is deemed effective if it offers a prospect of success, and it is found sufficient if it is capable of redressing the complaint." Dawda Jawara v. The Gambia, Comm. Nos. 147/95 \& 149/96, para. 31, AFr. COMM'N ON HUM. \& PEOPLeS' RTS., 13 ANN. ACTIVITY REP., Annex V (1999-2000), at http://www.achpr. org/files/activity-reports/13/achpr26and27_actrep13_19992000_eng.pdf. 
In the human rights context, an exhaustion requirement acts as a buffer between domestic and international legal systems. It "reinforces the subsidiary and complementary relationship of the international system to systems of internal protection," 125 and reflects a belief that domestic institutions should have "a first shot" at addressing human rights complaints. ${ }^{126} \mathrm{An}$ exhaustion rule also reduces "forum shopping and unnecessary rivalry between municipal and international courts," as well as the risk of conflicting decisions. ${ }^{127}$ Finally, it prevents international tribunals from being overburdened by a flood of human rights cases. ${ }^{128}$

Since granting the ECOWAS Court the authority to hear human rights cases, West African governments have repeatedly asserted that individuals must exhaust domestic remedies before petitioning the Court in Abuja. The judges have unwaveringly rebuffed these arguments, reasoning that the lack of an exhaustion rule is neither an inadvertent omission nor a flaw in the Court's human rights mandate, but a deliberately chosen element of its judicial architecture. ${ }^{129}$ Just as the judges in the Afolabi case refused to imply jurisdiction over suits by private parties, they have also held that non-exhaustion "cannot be taken away by implication" but requires an express amendment of the 2005 Protocol. ${ }^{130}$ Nor is the doctrine limited to situations where litigants have bypassed national proceedings. The ECOWAS Court has also decided cases that were pending before domestic courts, ${ }^{131}$ leading commentators to warn of potential conflicts between ECOWAS and national judges. ${ }^{132}$

\section{A Broad Authority for Human Rights Suits, but a Narrower Mandate for Economic Cases}

Why did the member states agree to give the Court such expansive authority to adjudicate human rights suits? And why did they allow direct access for human rights complaints but not for suits alleging violations of ECOWAS economic rules?

In our interviews, stakeholders suggested several plausible explanations. First, states appear to have accepted that the judges, secretariat officials, and civil society groups were acting in good faith and within the scope of their delegated authority. Participants in the court reform campaign underscored that their actions were consistent with ECOWAS rules. Community legal texts expressly authorize the judges to propose changes to the 1991 Protocol. They also

${ }^{125}$ Nsongurna Udombana, So Far, So Fair: The Local Remedies Rule in the Jurisprudence of the African Commission on Human and Peoples' Rights, 97 AJIL 1, 9 (2003).

${ }^{126}$ Ebobrah, supra note 9, at 88.

127 A. O. Enabulele, Sailing Against the Tide: Exhaustion of Domestic Remedies and the ECOWAS Community Court of Justice, 56 J. AFR. L. 268 (2012).

${ }^{128}$ Ebobrah, supra note 9, at 92.

${ }^{129}$ E.g., Saidykhan v. The Gambia, Ruling, supra note 110, para. 43 (explaining that "the Supplementary Protocol is an example of legislating out of the rule of customary international law regarding the exhaustion of local remedies"); Hadijatou Mani Kouraou v. Niger, Judgment, supra note 122, para. 45 (rejecting the argument that the lack of an exhaustion requirement is "a gap that should be filled" by judicial interpretation). Although states are free to dispense with an exhaustion of local remedies requirement, they have almost never done so for international human rights courts and review bodies. See supra note 123 .

130 Saidykhan v. The Gambia, Ruling, supra note 110, para. 42.

${ }^{131}$ E.g., Ayika v. Liberia, Case No. ECW/CCJ/APP/07/11, Ruling (Dec. 19, 2011); Hadijatou Mani Kouraou v. Niger, Judgment, supra note 122.

${ }^{132}$ Enabulele, supra note 127, at 293-94. The risk of conflict is mitigated by the ECOWAS Court's repeated assertion that it is not an appellate tribunal and will not generally review challenges to national court decisions. See, e.g., Keita v. Mali, Judgment, supra note 114, para. 31; Alade v. Nigeria, Judgment, supra note 114, paras. 34-35. 
empower NGOs to participate in discussions in ECOWAS forums. As for the Executive Secretariat, one of its key tasks is drafting protocols to ECOWAS legal instruments.

Second, all stakeholders supported giving the Court something to do. The frustration with idle judges was a direct, albeit unintended, artifact of the earlier decision to make the ECOWAS Court a full-time judicial body. The 2005 Protocol put cases on the Court's docket, and it gave member states a concrete way to fulfill their promise to make ECOWAS a more people-centered organization. Moreover, Community legal texts-in particular, the 2001 Good Governance Protocol— had clearly envisioned giving a human rights jurisdiction to the Court.

Third, human rights NGOs lobbied hard for a human rights jurisdiction and for the specific design features that we have highlighted. They argued that exhaustion would make it too difficult for West Africans to access the Court, especially since most countries "had weak judiciaries" and lacked "any functioning human rights apparatus." 133 They also highlighted frustrations with the African Commission on Human and Peoples' Rights' slow review of complaints and the spotty compliance with its nonbinding recommendations. ${ }^{134}$ ECOWAS officials were receptive to the advocates' concerns. They also recognized that an exhaustion requirement would do little to remedy the lack of cases on the Court's docket. ${ }^{135}$ As for the lack of enumerated human rights, governments apparently assumed that the references to the African Charter in the 1993 Treaty would lead the Court to view the Charter as the primary source of human rights norms in ECOWAS. ${ }^{136}$

Fourth, observers stressed that the 2005 Protocol-like other ECOWAS protocols-entered into force on a provisional basis. ${ }^{137}$ Governments may therefore have believed that the Court's human rights jurisdiction would be relatively easy to undo if the Court later behaved in ways that encroached on national sovereignty. The same rationale may also explain the protocol's other design features. For example, ECOWAS officials characterized the absence of an exhaustion requirement as an "experiment" that could be revisited in the future. ${ }^{138}$ As we explain below, however, despite the nominally provisional status of the 2005 Protocol, its acceptance as an ongoing feature of the Court became a political, if not a legal, fait accompli.

A final issue concerns the more circumscribed jurisdiction and access provisions for cases unrelated to human rights. The 2005 Protocol authorizes the ECOWAS Court to interpret all Community legal instruments and to determine the "failure by Member States to honor their obligations" under those instruments. ${ }^{139}$ Only member states and ECOWAS officials,

\footnotetext{
${ }^{133}$ Interview with Human Rights Advocate C, supra note 92.

${ }^{134}$ Interview with Academic A, in Abuja, Nigeria, and by telephone (Feb.-Mar. 2011); see also FrANS VilJOEN, INTERNATIONAL HUMAN RIGHTS LAW IN AFRICA 297, 487 (2d ed. 2012) (reviewing the "major impediments to the[] effectiveness and impact" of the African Commission on Human Rights and describing the Commission's "weaknesses ... in providing a credible and timely forum for ... recourse" to victims).

135 Interview with ECOWAS Legal Affairs Directorate B, supra note 98.

${ }^{136}$ Interview with Human Rights Advocate C, supra note 92.

${ }^{137}$ Interview with ECOWAS Legal Affairs Directorate A, supra note 62; Telephone interview with Human Rights Advocate A, supra note 91; Telephone interview with Human Rights Advocate B, supra note 48; Interview with ECOWAS Court Official C, in Abuja, Nigeria (Mar. 11, 2011).

${ }^{138}$ Interview with ECOWAS Legal Affairs Directorate A, supra note 62.

1392005 Protocol, supra note 103, Art. 3 (revising Article 9(1)(a), (b) \& (d) of the 1991 Protocol).
} 
however, can file such suits; individuals cannot. ${ }^{140}$ The Protocol does permit private actors to challenge actions or omissions of Community officials, ${ }^{141}$ and it authorizes national judges to refer to the Court, either "on [their] own or at the request of any of the parties," questions concerning the interpretation of ECOWAS legal texts. ${ }^{142}$ These reforms increase the Court's potential role in adjudicating challenges to noncompliance with ECOWAS economic rules. Despite the continuation of barriers to intraregional trade, however, no noncompliance suits have actually been filed by the secretariat or member states, and no national judges have referred cases to the Court. ${ }^{143}$ Part IV returns to this issue, delving further into the puzzle of why the Court's adjudicatory role in economic disputes remains virtually nonexistent.

\section{CHALLENGES TO THE ECOWAS COURT'S HuMAN RigHTS AUTHORITY}

In its eight years of operation as a human rights court, the ECOWAS Court has survived several political controversies and challenges. The first challenge stemmed from the Court's intervention in a contested Nigerian election — which triggered protests from Nigerian politicians, judges, and lawyers. A second, more serious threat involved an effort by the Gambia to curtail the Court's jurisdiction in response to decisions finding that state responsible for the torture of journalists. As we explain, the ECOWAS Court emerged from these two events largely unscathed and arguably strengthened. The third challenge, which is ongoing, focuses on improving member state compliance with the Court's judgments.

\section{A Controversial Intervention in a Nigerian Election Dispute and the Creation of the ECOWAS Judicial Council}

When the ECOWAS Court began to hear cases under its new human rights jurisdiction, some national judges and attorneys expressed concern that the Court would become embroiled in domestic political disputes. These concerns came to a head in 2005-the first year of the Court's new mandate — when the Court's president issued a controversial ruling in an election imbroglio involving a seat in the Nigerian Federal House of Representatives.

Jerry Ugokwe had been declared the winner of the election by the Independent National Electoral Commission. A Nigerian Elections Tribunal reversed the commission, finding that Ugokwe was ineligible to run for the seat. The Nigerian Federal Appeals Court — the final court of review for all election disputes in Nigeria - upheld Ugokwe's disqualification. ${ }^{144}$ Dissatisfied with this outcome, Ugokwe filed a complaint with the ECOWAS Court alleging a violation of his right to a fair hearing. ${ }^{145}$ Ugokwe asked the Court to issue a special interim order to

${ }^{140}$ Id., Art. 4 (inserting Article 10(a) \& (b) into the 1991 Protocol).

${ }^{141}$ Id. (inserting Article 10(c) into the 1991 Protocol).

${ }^{142}$ Id. (inserting Article 10(f) into the 1991 Protocol).

${ }^{143}$ Anene-Maidoh, supra note 113, at 9-10 (stating that the "concept of Preliminary Ruling as practiced by the [ECJ] is yet to take root in the context of regional integration in Africa").

${ }^{144}$ Lillian Okenwa, Election Petition: ECOWAS Court Stops Ugokwe's Successor, THIS DAY (Nigeria) (June 2, 2005), at http://allafrica.com/stories/200506030463.html.

${ }^{145}$ Iheanacho Nwosu, West Africa: I Am at ECOWAS Court to Get Fair Hearing-Hon. Ugokwe, DAILY CHAMPION (Nigeria) (June 21, 2005), at http://allafrica.com/stories/200506210089.html. 
prevent the Nigerian government from invalidating his election victory or from seating his opponent. ${ }^{146}$ President Donli issued the interim order barring the legislature from swearing in Okeke while Ugokwe's complaint was pending. ${ }^{147}$ Nigeria promptly sought to dismiss the suit for lack of jurisdiction, accusing Ugokwe of "forum shopping with courts." ${ }^{48}$ President Donli responded by renewing the interim order prior to leaving for a recess. ${ }^{149}$ These were audacious acts, but Donli publicly defended them as necessary, temporary measures to preserve the existence of a justiciable controversy until the judges could review Ugokwe's allegations. ${ }^{150}$

Notwithstanding concerns over the orders' validity, Nigerian officials complied with the Court's interim directive. The attorney general and minister of justice issued a request to the speaker of the House of Representatives "not to swear [Okeke] in until the case is fully settled by the [ECOWAS Court]." ${ }^{151}$ The request created a political uproar that spilled onto the front pages of the country's newspapers. Politicians, judges, and lawyers focused on a provision of the Nigerian Constitution that designates election disputes as exclusively domestic matters. ${ }^{152}$ They argued that this clause deprived the ECOWAS Court of jurisdiction to hear the election disputes. ${ }^{153}$

After returning from a month-long recess, the judges dramatically reversed course and dismissed the suit. They reasoned that "no provision, whether general or specific, gives the Court powers to adjudicate on electoral issues or matters arising thereof." ${ }^{154}$ They also asserted that the ECOWAS Court "is not a Court of Appeal or a Court of cassation" over domestic courts. The judges thus declared themselves without authority to intervene "against the execution of the Judgment already made by the Federal Appeal Court of the Member State of Nigeria."155 The judges did not explain the about-face from the preliminary order, but the categorical nature of the decision suggests that they wanted to send a clear message that they would not intervene in future election disputes.

The Court's dramatic change of position did little, however, to quell the underlying legal and political controversy. As one Community official observed, "national high courts were

\footnotetext{
${ }^{146}$ Specifically, Ugokwe requested a "special interim order" enjoining (1) the INEC from (a) invalidating Ugokwe's election or (b) "tak[ing] any steps" toward his replacement, and (2) the Federal National Assembly from relieving Ugokwe of his seat. Ugokwe v. Nigeria, Case No. ECW/CCJ/APP/02/05, Judgment, paras. 7, 14.2-.3 (Oct. 7 , 2005), reprinted in 2004-09 COMMUNITY COURT OF JUSTICE, ECOWAS LAW REPORT 37 (2011).

147 Okenwa, supra note 144.

${ }^{148}$ FG Asks ECOWAS Court to Dismiss Ugokwe Suit, VANGUARD (Nigeria) (June 17, 2005), at http://all africa.com/stories/200506170727.html.

${ }^{149}$ Ise-Olu-Oluwa Ige, ECOWAS Court Goes on Recess, VANGUARD (Nigeria) (July 7, 2005), at http://all africa.com/stories/200507070032.html.

${ }^{150}$ Okenwa, supra note 144.

${ }^{151}$ Ugokwe v. Nigeria, Judgment, supra note 146, para. 10.

${ }^{152}$ Constitution of the Federal Republic of Nigeria, Art. 246(3), 1999, at http://www.nigeria-law.org/ ConstitutionOfTheFederalRepublicOfNigeria.htm\#CourtOfAppeal.

${ }^{153}$ Ige, supra note 149; Okenwa, supra note 144. The individuals whom we interviewed repeated these arguments. Telephone interview with Academic A (Jan. 6, 2011); Interview with Human Rights Advocate C, supra note 92; Interview with ECOWAS Legal Affairs Directorate A, supra note 62; Interview with ECOWAS Legal Affairs Directorate B, supra note 98.

${ }^{154}$ Ugokwe v. Nigeria, Judgment, supra note 146, para. 19.

${ }^{155}$ Id., paras. 32, 33.
} 
upset that [ECOWAS] judges with less qualifications and experience than they had could issue rulings that would be final and binding on them." 156 The Ugokwe case exacerbated these anxieties by putting the ECOWAS Court in direct conflict with the Nigerian judiciary and political establishment.

The member states responded to these concerns by creating a new ECOWAS institution that appears to have enhanced the Court's independence and authority. In 2006, as part of a wider overhaul of the Community, ${ }^{157}$ the member states created a Judicial Council ${ }^{158}$ "to ensure that the Court is endowed with the best qualified and competent persons to contribute . . to the establishment of Community laws capable of consolidating and accelerating the regional integration process." 159 The council comprises the chief justices from member states not then represented on the seven-member Court. ${ }^{160}$

The Judicial Council increases the influence of national judges in the selection process for the ECOWAS Court, and it creates misconduct review procedures that insulate judges from attempts by governments to remove them from office. ECOWAS judges are "statutory appointments"- high-level positions that rotate among the member states. West African governments collectively decide which country is next in line for a statutory appointment to the Court. The Legal Affairs Directorate then advertises for the position and collects submissions from eligible applicants. Applications that meet specified criteria are forwarded to the Judicial Council, which vets applications and interviews candidates. The council then selects three candidates and forwards their names, together with point-based rankings, to the ECOWAS Authority, which decides which candidate to appoint to the Court. For sitting judges, the Council is tasked with reviewing complaints alleging judicial bias and other forms of malfeasance, providing a layer of political insulation for ECOWAS judges against whom such charges are filed. ${ }^{161}$

Also included in the Judicial Council reforms was a revision of the tenure of ECOWAS judges - from a five-year term with the possibility of one reappointment to a single, nonrenewable four-year term. ${ }^{162}$ Secretariat officials explained this reform as a way to bring judicial appointments to the Court in line with other statutory appointments in the Community. Although the shortening of terms may seem like a rebuke of the ECOWAS Court, no one we interviewed characterized the change in this way. Rather, they noted that shorter, nonrenew-

\footnotetext{
${ }^{156}$ Interview with ECOWAS Legal Affairs Directorate A, supra note 62; see also Donald Andoor, Nigeria: Ugokwe Loses House Seat, THIS DAY (Nigeria) (Sept. 22, 2005), at http://allafrica.com/stories/ 200509230288.html.

157 ECOWAS NEWSLETTER, no. 1, Oct. 2006 (describing institutional changes), at http://www.ecowas.int/ publications/en/newsletter/ECOWAS_NewsLetter_01-Eng.pdf.

${ }_{158}$ Decision A/Dec.2/06/06 Establishing the Judicial Council of the Community (adopted June 14, 2006) (on file with authors).

${ }^{159}$ ECOWAS NEWSLETTER, supra note 157 , at 4.

${ }^{160}$ Decision A/Dec.2/06/06, supra note 158, Arts. 1, 2.

${ }^{161}$ Regulation C/Reg.23/12/07, Adopting the Rules of Procedure of the Community-Judicial Council, Art. 5, Dec. 14-15, 2007 (on file with authors). The dismissal of judges for politically unpopular rulings has been a significant concern in the East African Community legal system. James T. Gathii, Mission Creep or a Search for Relevance: The East African Court of Justice's Human Rights Strategy, 24 DUKE J. COMP. \& INT'L L. (forthcoming 2014) (manuscript at 24-25) (on file with authors).

${ }^{162}$ This reform amends Article 4 of the 1991 Protocol. See ECOWAS NEWSLETTER, supra note 157, at 4.
} 
able terms would increase the opportunity of all ECOWAS member states to appoint judges to the Court. ${ }^{163}$

The Judicial Council and tenure reforms have been favorably received by stakeholders. As one lawyer noted, "Now that the Judicial Council exists, the stature of the Court will be higher, which will improve the quality of judges [since] more qualified candidates will apply." 164 The process is still relatively new, however, and only one set of appointments has been made using the new procedures: in 2008, the ECOWAS Authority approved the slate of judges recommended by the council. ${ }^{165}$ In addition, some concerns over judicial qualifications persist - in particular, the absence of a requirement that judges be well versed in international human rights law. ${ }^{166}$

\section{The Gambia's Proposal to Restrict the ECOWAS Court's Human Rights Jurisdiction}

The next political flashpoint for the ECOWAS Court concerned two decisions against the Gambia - both finding that state responsible for the disappearance and torture of journalists - that were widely viewed as legally sound, albeit politically audacious. Unable to challenge the judgments as poorly reasoned or as an improper interference with domestic authority, the Gambia launched a campaign in 2009 to narrow the Court's human rights jurisdiction.

The case of Chief Ebrima Manneh involved a reporter for the Daily Observer who disclosed information that appeared in a news article critical of the government. ${ }^{167}$ Plainclothes intelligence agents arrested Manneh in July 2006. He disappeared until January 2007, when reports emerged that he was being detained at a local police station. Intelligence and police officials denied that he was in their custody. ${ }^{168}$ In May 2007, the NGO Media Foundation for West Africa filed a complaint with the ECOWAS Court charging the Gambia with numerous human rights abuses, demanding Manneh's release, and requesting compensation for his injuries. ${ }^{169}$ The Gambia refused to respond to the complaint and ignored multiple requests to appear or

\footnotetext{
${ }^{163}$ Interview with ECOWAS Legal Affairs Directorate A, supra note 62. Other studies have found that international judges who are ineligible for reappointment are more likely to rule against the governments that appointed them. Erik Voeten, The Impartiality of International Judges: Evidence from the European Court of Human Rights, 102 AM. POL. SCI. REV. 417, 427 (2008).

${ }^{164}$ Interview with Human Rights Advocate C, supra note 92.

${ }^{165}$ African Press Organization, ECOWAS Council of Ministers Seeks Regional Infrastructural Development (Nov. 30, 2008) (reporting results of a 2008 meeting of the ECOWAS Council of Ministers at which the "Council ... endorsed the report of the ECOWAS Judicial Council on the appointment of three new judges" for the Court), at http://appablog.wordpress.com/2008/11/30/burkina-faso-ecowas-council-of-ministers-seeks-regionalinfrastructural-development/; Interview with ECOWAS Legal Affairs Directorate B, supra note 98.

166 Solomon T. Ebobrah, A Critical Analysis of the Human Rights Mandate of the ECOWAS Community Court of Justice $47 \mathrm{n} .194$ (2008) (noting statement by ECOWAS Court vice president that "the human rights competence of prospective appointees should be taken into consideration" even though such competence is not expressly stated as a criterion for appointment), at http://www.humanrights.dk/files/doc/forskning/Research\%20partnership\%20 programme\%20publications/S.Ebobrah.pdf.

${ }^{167}$ IPI Calls on the Gambian Government to Cooperate with ECOWAS Legal Proceedings, FREEDOM NEWSPAPER (Mar. 13, 2008), at http://www.freemedia.at/press-room/public-statements/press-releases/singleview/article/ipicalls-on-the-gambian-government-to-cooperate-with-ecowas-legal-proceedings.html.

${ }^{168}$ Manneh v. The Gambia, Case No. ECW/CCJ/APP/04/07, Judgment, paras. 7-8 (June 5, 2008), reprinted in 2004-09 COMMUNITY COURT OF JUSTICE, ECOWAS LAW REPORT 181 (2011), available at http:// www1.chr.up.ac.za/index.php/browse-by-institution/ecowas-ccj.html.

${ }^{169} I d$., para. 3.
} 
file documents, delaying the proceedings. ${ }^{170}$ In June 2008, the Court ruled for Manneh, ordering the Gambia to release him from "unlawful detention without any further delay," pay him U.S. $\$ 100,000$ in damages, and bear the costs of the litigation. ${ }^{171}$

The Gambia ignored the judgment — a decision that received a great deal of unfavorable publicity from governments, international organizations, and NGOs. ${ }^{172}$ For example, the International Press Institute publicly stated that the "Gambian media environment has long been hostile and dangerous, but the government's flagrant disregard for the ECOWAS legal proceedings represents a low point." ${ }^{173}$ Likewise, the African Commission on Human Rights called on the Gambia "to immediately and fully comply" with the ECOWAS Court's judgment. ${ }^{174}$

The second case, concerning the detention and torture of Musa Saidykhan, was harder for the government to ignore, because the plaintiff was alive, exhibited clear evidence of torture, and pursued the case from the safety of another country. ${ }^{175}$ After a coup attempt in 2006, the Independent newspaper published the names of individuals that the Gambian National Intelligence Agency had arrested. Shortly thereafter and without a warrant, soldiers and policemen arrested Saidykhan, the newspaper's editor. ${ }^{176}$ Security agents took Saidykhan to a detention center, where he was held for twenty-two days and repeatedly tortured. ${ }^{177}$ Intelligence officials eventually released Saidykhan, but they continued to monitor his movements and threatened his family, ultimately causing Saidykhan and his family to flee the country. ${ }^{178}$

In 2007, Saidykhan, supported by the Media Foundation for West Africa, filed a complaint with the ECOWAS Court seeking a declaration that his arrest and detention were illegal and that he had been tortured and denied a fair hearing. ${ }^{179}$ This time, the Gambia participated in the proceedings. It asked the ECOWAS Court to dismiss the suit on the grounds that the Court lacked jurisdiction, that the Court's intervention was "an affront to [its] sovereignty," and that the suit should be heard by a national court. ${ }^{180}$ In 2009, the Court issued an interim ruling rejecting these arguments. ${ }^{181}$

The Gambia's political attack on the ECOWAS Court occurred while the merits phase of Saidykhan was pending. Gambian officials noted that the government was "aggrieved" by the

${ }^{170} I d$., paras. 4, 28.

${ }^{171}$ Id., para. 44.

${ }^{172}$ E.g., U.S. Senators Call for Release of Journalist, FOROYAA NEWSPAPER (Serrekunda) (Apr. 28, 2009), at http://business.highbeam.com/437649/article-1G1-198772071/us-senators-call-release-journalist; Durbin, Other Senators Press Commonwealth Nations on Case of Missing Journalist, STATES NEWS SERVICE, Mar. 18, 2010 (on file with authors), available at http:/www.highbeam.com/doc/1G1-221599405.html.

${ }^{173}$ International Press Institute, IPI Calls on the Gambian Government to Cooperate with ECOWAS Legal Proceedings, SENEGAMBIA NEwS (Mar. 13, 2008), at http://www.freemedia.at/archives/singleview/article/ipi-calls-onthe-gambian-government-to-cooperate-with-ecowas-legal-proceedings.html.

${ }^{174}$ Linda Akrasi Kotey, Ghana:Akoto Ampaw, Two Others in Gambia, GHANAIAN CHRONICLE (July 17, 2009), at http://allafrica.com/stories/200907171086.html.

${ }^{175}$ ECOWAS Torture Case Against the Gambia Nears an End, AFROL NEWS (Sept. 22, 2010), at http://www. afrol.com/articles/36623.

176 Saidykhan v. The Gambia, Ruling, supra note 110, para. 4.

${ }^{177}$ Id., para. 7.

${ }^{178}$ Id., paras. 8-9.

${ }^{179} I d$., para. 2.

${ }^{180}$ Id., para. 11.

${ }^{181}$ Id., para. 37. 
judgment in the Manneh case and had "set the political process in motion to take the matter to the next level and get the decision set aside." ${ }^{182}$ In September 2009, the Gambia called for a Meeting of Government Experts to revise the 2005 Protocol and restrict the Court's authority. ${ }^{183}$ Most importantly, the Gambia sought to limit the ECOWAS Court's human rights jurisdiction to treaties ratified by the respondent state and to require exhaustion of domestic remedies. $^{184}$

On their face, these proposals seem uncontroversial. As noted above, other international human rights tribunals operate under similar limitations. According to a consortium of NGOs, however, the "Gambian government propose[d] these amendments so that the Court will be weakened in its capacity to deal effectively with tyrannical governments trampling on citizens' rights." In the NGOs' view, the proposal to require exhaustion of local remedies aimed to "depriv[e] citizens of free access" to an "independent judicial instrument that is not usually available in many countries" in a region "where the judiciary is an arm of the executive." And the attempt to limit the ECOWAS Court's jurisdiction to ratified human rights treaties was a ploy "to prevent the Court from adjudicating on the [Saidykhan] case against The Gambia""one of the rare African countries which has not ratified" the UN Convention Against Torture. $^{185}$

The ECOWAS Commission (which, under the 2006 reorganization mentioned above, replaced the Executive Secretariat) responded to the Gambian proposals by invoking the procedures for public participation in ECOWAS decision making. The commission also invited West African lawyers to consider the proposed, multipart amendment. ${ }^{186}$ Based on their input, the ECOWAS Committee of Legal Experts recommended against narrowing the Court's human rights jurisdiction. In October 2009, the Council of Justice Ministers unanimously endorsed the committee's recommendation-with the consequence that the proposals were implicitly rejected at a meeting of the Council of Foreign Ministers the following month. ${ }^{187}$

The Gambia's proposals provided a clear opportunity for ECOWAS member states to reconsider the 2005 Protocol. Their decision to reject the Gambian challenge is striking. In our interviews, officials offered different explanations for this decision. One source explained that governments did not want to reward the Gambia for its poor human rights record. These

182 Gambian Attorney-General Denies Holding Missing Journalist, AGENCE FrANCE PRESSE, Apr. 7, 2009.

183 West Africa: Country Submits Proposals to Amend ECOWAS Protocol, FOROYAA NEWSPAPER (Serrekunda) (Sept. 25, 2009), at http://allafrica.com/stories/200909250810.html; see also Nana Adu Ampofo, Gambian Authorities Seek to Limit Reach of Regional Human Rights Court, GLOBAL INSIGHT (Sept. 28, 2009) (on file with authors); Innocent Anaba, SERAP, CHRDA Challenge Plans to Amend ECOWAS'Court Powers, VANGUARD (Nigeria), June 26, 2008 (on file with authors).

${ }^{184}$ The Gambia also proposed that cases should be admissible for only twelve months after the exhaustion of domestic remedies, that applicants should not be anonymous, and that complaints submitted to the ECOWAS Court should be barred from later being filed with other international courts. The Gambia reiterated the need for a process to appeal all ECOWAS Court decisions. West Africa: Country Submits Proposals to Amend ECOWAS Protocol, supra note 183 .

${ }^{185}$ Four IFEX Members, Civil Society Groups Fear Gambia Proposal Will Prevent ECOWAS Court from Ruling in Saidykhan Case, IFEX (Sept. 28, 2009), at http://www.ifex.org/west_africa/2009/09/28/ecowas_court_ jurisdiction/.

${ }^{186}$ Id.; Interview with Human Rights Advocate C, supra note 92.

${ }^{187}$ Justice Ministers Endorse Experts' Decision on ECOWAS Jurisdiction, IFEX, (Oct. 14, 2009), at http:// www.ifex.org/west_africa/2009/10/14/gambian_proposal_defeated/. One source told us that, while the justice ministers unanimously rejected the Gambia's proposals, the foreign ministers were split, with one-third supporting and two-thirds opposing the proposals. Telephone interview with Human Rights Advocate A, supra note 91. 
governments recognized that Gambian officials were acting in a blatantly "self-interested way" by attempting to circumvent the Court's review of serious and widely known human rights abuses. ${ }^{188}$ Also important were the mobilization efforts of human rights NGOs and attorneys, who made sure that the issues were well covered in the press. One interviewee even suggested that ECOWAS officials had a hand in opposing the Gambian proposals by leaking information to human rights lawyers. ${ }^{189}$

In December 2010, the ECOWAS Court issued a judgment holding the Gambia responsible for the illegal detention and torture of Saidykhan and ordering the state to pay him U.S.\$200,000 in damages. ${ }^{190}$ The Gambia has refused to comply, however, with either the Saidykhan or the Manneh judgments. In 2011, in addition to denying responsibility for Manneh's death, ${ }^{191}$ the Gambia asked the Court to set aside both judgments, and attacked Saidykhan as a "miscarriage of justice since the court failed to properly appraise the evidence on record." The Media Foundation for West Africa opposed the application and reiterated its demands for compliance. ${ }^{192}$ In 2012, the judges rejected the Gambia's arguments and reaffirmed the two judgments and remedial orders. ${ }^{193}$

Although the Gambia continues to resist the ECOWAS Court's authority, the defeat of its judicial reform campaign has had the opposite of its intended effect: it has bolstered the Court's legitimacy. As previously explained, the 2005 Protocol entered into force provisionally pending ratification by individual member states, a process that is still ongoing. In 2006, however, West African governments restructured ECOWAS rulemaking to increase its supranational character. The reforms authorize the Authority to adopt "supplementary acts." These legal instruments are equivalent to protocols but with one crucial difference-they are "binding on Member States and the institutions of the Community" without the need for country-bycountry ratification. ${ }^{194}$

The effect of these reforms on previously adopted protocols is unclear. One attorney worried that the continuation of the 2005 Protocol's provisional status remains a potential "liability" for the ECOWAS Court. ${ }^{195}$ Even if this interpretation is correct as a legal matter, those whom

\footnotetext{
${ }^{188}$ Interview with ECOWAS Legal Affairs Directorate A, supra note 62.

${ }^{189}$ Interviews with Human Rights Advocates B, supra note 48, C, supra note 92; Interview with ECOWAS Legal Affairs Directorate A, supra note 62; see also Four IFEX Members, Civil Society Groups Fear Gambia Proposal Will Prevent ECOWAS Court from Ruling in Saidykhan Case, supra note 185 (listing regional civil society groups that mobilized against the Gambia's proposals).

190 Saidykhan v. The Gambia, Case No. ECW/CCJ/APP/11/07, Judgment, para. 47 (Dec. 16. 2010); see also Ousman Njie, ECOWAS Court Awards Musa Saidykhan \$200,000, FOROYAA NEWSPAPER (Serrekunda) (Dec. 17, 2010), at http://www.foroyaa.gm/international-news/7445-gambia-news-archive.

${ }^{191}$ In 2011, the country's president suggested that Manneh had died but that "the government has nothing to do with" his death. Critical Activists and Journalists Detained Under "Bogus Charges," IFEX (July 27, 2011), at http://www.ifex.org/the_gambia/2011/07/27/bogus_charges/.

${ }^{192}$ Media Foundation for West Africa, Alerts and Updates 2011: ECOWAS Court Adjourns Hearing on Gambian Government Request for Review of Two Landmark Judgements (Dec. 29, 2011), at http://www.mediafound.org/? $\mathrm{p}=3188$.

193 Saidykhan v. The Gambia, Case No. ECW/CCJ/APP/11/07, Application for Review (Feb. 7, 2012); see Gambia: ECOWAS Court Rules in Favour of Musa Saidykhan, FOROYAA NEWSPAPER (Serrekunda) (Feb. 11, 2012), at http://allafrica.com/stories/201202140302.html.

${ }^{194}$ ECOWAS NEWSLETTER, supra note 157, at 2.

195 Telephone interview with Human Rights Advocate A, supra note 91.
} 
we interviewed all agreed that the rejection of the Gambia's proposals made the Protocol's provisional status a non-issue politically. ${ }^{196}$ Having survived this attempt to curb its jurisdiction, the Court's human rights authority now rests on a more solid foundation than when the member states first gave the Court that authority in 2005 .

\section{Strategies to Promote Compliance: Strict Proof Requirements, Limited Remedies, and Public Outreach}

Since the expansion of its jurisdiction in 2005, the ECOWAS Court has issued nearly seventy merits judgments, the large majority of which concern human rights. ${ }^{197}$ Many of these decisions are legally and politically consequential. In a well-publicized early case, ECOWAS judges found Niger liable for condoning a customary practice of female slavery. ${ }^{198}$ More recently, the Court issued a pathbreaking judgment against Nigeria for failing to regulate multinational oil companies that polluted the Niger Delta. ${ }^{199}$ Other high-profile decisions have barred the domestic prosecution of former Chadian president Hissein Habré as contrary to the nonretroactivity of criminal law; ${ }^{200}$ ordered the restoration of funds embezzled from a program to provide free basic education to children; ${ }^{201}$ granted NGOs standing to challenge violations of economic and social rights; ${ }^{202}$ and awarded damages to individuals arbitrarily detained by police and security officials. ${ }^{203}$

These decisions grab headlines, and they significantly enhance the Court's salience and visibility across West Africa. ${ }^{204}$ It is less clear, however, whether these decisions have improved respect for human rights in the region. ${ }^{205}$ According to a 2013 paper by the Court's chief reg-

196 Interview ECOWAS Legal Affairs Directorate A, supra note 62; Interview with Human Rights Advocate C,
supra note 92; Interview with ECOWAS Court Official C, supra note 137 .
197 As of July 2013, the ECOWAS Court's decisions included seventeen rulings and sixty-seven judgments on the
merits. Amie Sanneh, West Africa: ECOWAS Court of Justice Briefthe Press, FOROYAA NEWSPAPER (Serrekunda)
(July 26, 2013) (reporting statement of the ECOWAS Court chief registrar), at http://allafrica.com.
proxy.lib.duke.edu/stories/201307291277.html. Solomon Ebobrah has provided the most detailed analysis of the
ECOWAS Court's human rights jurisprudence. See, e.g., Ebobrah, Critical Issues, supra note 112 .
${ }^{198}$ Hadijatou Mani Kouraou v. Niger, Judgment, supra note 122 .
${ }^{199}$ Socio-Economic Rights and Accountability Project v. Nigeria, Case No. ECW/CCJ/APP/08/09, Judgment
(Dec. 14, 2012) [hereinafter SERAP Niger Delta Judgment].
${ }^{200}$ Habré v. Senegal, Case No. ECW/CCJ/APP/07/08, Judgment (Nov. 18, 2010).
${ }^{201}$ Socio-Economic Rights and Accountability Project v. Nigeria, Case No. ECW/CCJ/APP/08/08, Judgment (Nov. 30, 2010) [hereinafter SERAP Basic Education Judgment].

202 SERAP Basic Education Ruling, supra note 109.

${ }^{203}$ E.g., Alade v. Nigeria, Judgment, supra note 114; Tandja v. Niger, Case No. ECW/CCJ/APP/05/10, Judgment (Nov. 8, 2010).

${ }^{204}$ One indication of this salience is the increasing discussion of ECOWAS Court cases in the West African news media. A search for "ECOWAS Court" and "Community Court of Justice" on AllAfrica.com—a news aggregator Web service-yielded the following number of "hits" each year:

\begin{tabular}{|c|c|c|c|c|c|c|c|c|c|c|c|}
\hline 2001 & 2002 & 2003 & 2004 & 2005 & 2006 & 2007 & 2008 & 2009 & 2010 & 2011 & 2012 \\
\hline 6 & 4 & 2 & 12 & 50 & 28 & 47 & 61 & 53 & 67 & 79 & 90 \\
\hline
\end{tabular}

${ }^{205}$ Article 15(4) of the 1993 Treaty, supra note 37, provides that the ECOWAS Court's judgments "shall be binding on the Member States, the Institutions of the Community and on individuals and corporate bodies," and Article 19(2) of Protocol A/P.1/7/91 on the Community Court of Justice, supra note 61, makes the Court's decisions "final and immediately enforceable." As with other international courts, however, the ECOWAS Court does "not have the benefit of institutions with powers of coercion to enforce [its] judgments" and has to rely on "pressure generated 
istrar, "not many decisions of the Court have been enforced."206 Perhaps aware of the challenges of inducing governments to comply with its judgments, the Court has tempered the legal and political impact of its decisions by requiring applicants to provide persuasive proof that the relevant human rights norms are widely accepted and by limiting the remedies that it demands of governments.

Complainants have raised a wide array of legal issues before the ECOWAS Court. Some allegations relate to human rights only tangentially; others seek expansive interpretations of established rights; still others allege multiple violations but offer few supporting facts. The Court has responded to these diverse complaints by adopting fairly strict pleading and proof requirements. Applicants must "specify the particular human right which has been violated" 207 and provide evidence that is "sufficiently convincing and unequivocal." ${ }^{208}$ ECOWAS judges have also rejected litigants' attempts to assert human rights claims against individuals, corporations, and subnational political bodies ${ }^{209}$ _issues that have also been litigated in the United States. ${ }^{210}$

The judges' circumspection with regard to remedies is also noteworthy. In the modern forms of slavery case, for example, the Court ordered Niger to pay the equivalent of U.S.\$20,000 to a woman who had been enslaved. ${ }^{211}$ The government paid the damages within three months, and, while not formally required to do so, prosecuted her former master. ${ }^{212}$ Yet the Court made compliance fairly easy for Niger by refusing the applicant's entreaties to find fault with the laws, practices, and customs that gave rise to the modern slavery violations in the first instance. ${ }^{213}$

Other high-profile decisions exhibit similar remedial caution. In the Nigerian education case, the ECOWAS Court declared that "every Nigerian child is entitled to free and compulsory basic education." ${ }^{214}$ Yet it did not order the government to allocate whatever funds were required to educate all primary school age children. Instead, based on evidence that specific funds had been embezzled from the national education program, the Court ordered Nigeria to "take the necessary steps to provide the money to cover the shortfall" while the government pursued efforts "to recover the funds or prosecute the suspects." 215

by the political arms of [the Community], the indulgence of national executives or the goodwill of national courts." Ebobrah, supra note 9, at 96.

${ }^{206}$ Anene-Maidoh, supra note 113, at 27.

${ }^{207}$ Keita v. Mali, Judgment, supra note 114, para. 33.

${ }^{208}$ Garba v. Benin, Case No. ECW/CCJ/APP/09/08, Judgment, para. 39 (Feb. 17, 2010). The Court recently reaffirmed this evidentiary standard and extended it to defenses raised by states. Alade v. Nigeria, Judgment, supra note 114 , paras. $48-50$.

209 See, e.g., David v. Uwechue, Ruling, supra note 121, para. 48 (individuals); Hassan v. Nigeria, Case No. ECW/CCJ/APP/03/10, Judgment, para. 41 (Mar. 15, 2012) (subnational political entities and their officials); SERAP Niger Delta Ruling, supra note 109, paras. 69-71 (corporations).

${ }^{210}$ E.g., Kiobel v. Royal Dutch Petroleum Co., 133 S.Ct. 1659 (2013) (Alien Tort Statute does not apply to human rights violations by foreign corporations committed on the territory of another state); Mohamad v. Palestinian Authority, 132 S.Ct. 1702 (2012) (only individuals, not corporate entities, can be liable under the Torture Victim Protection Act); Samantar v. Yousuf, 560 U.S. 305 (2010) (foreign official sued for conduct undertaken in his official capacity is not a "foreign state" entitled to immunity from suit).

${ }^{211}$ Hadijatou Mani Koraou v. Niger, Judgment, supra note 122, para. 92.

${ }^{212}$ Helen Duffy, Human Rights Cases in Sub-regional A frican Courts: Towards Justice for Victims or Just More Fragmentation, in THE DIVERSIFICATION AND FRAGMENTATION OF INTERNATIONAL CRIMINAL LAW 163, 179-81 (Larissa van den Herik \& Carsten Stahn eds., 2012).

${ }^{213}$ ALTER, supra note 8, at 264-66.

${ }^{214}$ SERAP Basic Education Judgment, supra note 201, para. 26.

${ }^{215}$ Id., para. 28. 
The judges took a different tack in a judgment touching the "third rail" of Nigerian politics - the activities of multinational oil companies in the Niger Delta. The Court declared that Nigeria was responsible for failing to regulate companies that had despoiled the area. It rejected a demand, however, for U.S.\$1 billion in damages on the ground that the applicants had not identified particular victims and that awarding mass damages would be impractical "in terms of justice, morality and equity." 216 The judges instead ordered Nigeria to "take all measures" to restore the environment, prevent future damage, and hold the perpetrators accountablewithout, however, specifying how the government was to achieve these goals. ${ }^{217}$

Strict proof requirements and limited remedies may be strategically wise choices for a young human rights court whose judgments have yet to elicit widespread compliance. A 2012 NGO report supports this conclusion. In addition to full compliance in the Hadijatou Mani Koraou slavery case against Niger, the report lists a few instances of partial compliance, ${ }^{218}$ including the Habré decision against Senegal, the release of the former president of Niger from house arrest, and the payment of damages to members of the Togolese Parliament wrongfully removed from office. ${ }^{219}$ Other judgments, including the high-profile decisions against Nigeria and the Gambia discussed above, have yet to garner even partial compliance. $^{220}$

ECOWAS judges readily admit these compliance challenges. In 2012, the current ECOWAS Court president, Awa Nana Daboya, publicly "decried the attitude of the Nigerian government for not honoring any of" the ten merits judgments that the Court had issued against that country. ${ }^{221}$ At the same time, the Court has praised those countries — including Nigeria — that have designated a public ministry to oversee the implementation of its judgments. And it has discussed ways to promote compliance in meetings with government officials and national judges. ${ }^{222}$ Civil society groups have added their voices to these efforts, issuing public declarations demanding that states comply with ECOWAS Court decisions and urging Community officials to step up enforcement efforts. ${ }^{223}$ A few political leaders have also expressed support

\footnotetext{
216 SERAP Niger Delta Judgment, supra note 199, paras. 113-15.

${ }^{217}$ Id., para. 121.

${ }^{218}$ Recent studies suggest that partial compliance is the norm for human rights tribunals. See, e.g., Darren Hawkins and Wade Jacoby, Partial Compliance: A Comparison of the European and Inter-American Court of Human Rights, 6 J. INT'L L. \& INT'L REL. 35, 56-83 (2010); Alexandra Huneeus, Courts Resisting Courts: Lessons from the InterAmerican Court's Struggle to Enforce Human Rights, 44 CORNELL INT'L L.J. 493, 509-29 (2011).

${ }^{219}$ Horace Adjolohoun, Status of Human Rights Judgments of the ECOWAS Court: Implications on Human Rights and Democracy in the Region (Aug. 7, 2012) (on file with authors).

$220 \mathrm{Id}$.

${ }^{221}$ Eyo Charles, West Africa: Nigeria Doesn't Respect Our Rulings—ECOWAS Court, DAILY TRUST (Mar. 13, 2012), at http://allafrica.com/stories/201203130408.html.

${ }^{222}$ E.g., Community Court of Justice, ECOWAS, Summary of Activities for the Year 2011, at 5 (2012), available at http://www.courtecowas.org/site2012/pdf_files/annual_reports/activities_report_2011.pdf; Press Release, Media Foundation for West Africa, MFWA Holds Forum on ECOWAS Court in Abuja (July 27, 2012), at http://www.mediafound.org/index.php?option=com_content\&task= view\&id $=857$.

${ }^{223}$ Bassey Udo, West Africa: Human Rights Groups Want Mechanism to Enforce ECOWAS Court Decisions, PREMIUM TiMES (Nigeria) (May 2, 2013), at http://allafrica.com/stories/201305020992.html; Media Foundation for West Africa Abuja Declaration of the Regional Civil Society Forum on the Enforcement of Judgements of the ECOWAS Community Court of Justice (July 30, 2012), at http://www.mediafound.org/en/?p=3073; Press Release, Media Foundation for West Africa, ECOWAS Commission Commits to Ensuring Member States Comply with Decisions of the Community Court of Justice (Nov. 15, 2012) (on file with authors).
} 
for compliance in specific cases, even when the government as a whole remains noncommittal. $^{224}$

Pressure for compliance also comes from outside ECOWAS. For example, the disappearance of Chief Ebrima Manneh, the applicant in the 2008 unlawful detention case discussed above, was raised in 2010 during the Universal Periodic Review of the Gambia before the UN Human Rights Council. ${ }^{225}$ Recent human rights reports by the United States and the United Kingdom also highlight the Gambia's continued noncompliance with the ECOWAS Court's judgments. $^{226}$

In sum, although the ECOWAS Court is still a young international tribunal with an uncertain future, the Court has survived two major challenges to the exercise its human rights authority, arguably emerging stronger for having weathered those travails. The judges are also aware of ongoing concerns about noncompliance and are responding both in their jurisprudence and in actions outside the courtroom. Finally, as we discuss below in our conclusion, the ECOWAS Court's status as a human rights court is far more settled than that of subregional community courts elsewhere in Africa.

\section{EXPLAINING INSTITUTIONAL CHANGE: THEORETICAL IMPLICATIONS OF THE ECOWAS COURT'S REDEPLOYMENT AS A HUMAN RIGHTS COURT}

This part considers the theoretical implications of the ECOWAS Court's redeployment. The broad delegation of human rights authority to the ECOWAS Court is likely to elicit incredulity from those who expect African leaders to be jealous of their sovereignty and to tightly control the international institutions that they create. This expectation is reflected in rational functionalist international relations theory, which assumes that states delegate authority to international institutions only when doing so furthers narrowly conceived functional objectives. We agree that state interests and sovereignty matter, and that the creation of a far-reaching and domestically intrusive international human rights review mechanism in West Africa is surprising. We are not, however, surprised that an international institution created to achieve one objective evolved to take on very different functions or that such an institution developed in a way that constrains the discretion of governments.

In the subsections that follow, we contrast rational functionalist theories with historical institutionalist accounts, which recognize that institutions can evolve over time to become quite different from what the founders first envisioned. We then return to part I's discussion of how the humanitarian interventions of the 1990s reoriented regional politics and ECOWAS institutions in ways that opened a door for NGOs, Community officials, and judges to expand

${ }^{224}$ E.g., Socio-Economic Rights and Accountability Project, Senate President Wants Action on ECOWAS Right to Education Judgment (n.d.) (stating that the head of the Nigerian Senate was the "first political leader to acknowledge the [SERAP Basic Education Judgment] and to take action towards its implementation"), at http://serap-nigeria.org/ senate-president-wants-action-on-ecowas-right-to-education-judgment/.

${ }^{225}$ UN Human Rights Council, Report of the Working Group on the Universal Periodic Review: Gambia, UN Doc. A/HRC/14/6, at 4, 21 (Mar. 24, 2010), at http://daccess-dds-ny.un.org/doc/UNDOC/GEN/G10/ 125/20/PDF/G1012520.pdf?OpenElement.

${ }^{226}$ U.S. Department OF STATE, COUNTRY Reports ON Human RightS Practices FOR 2012: THE GAMBIA, at http://www.state.gov/j/drl/rls/hrrpt/humanrightsreport/index.htm?year=2012\&dlid=204123; FOREIGN AND COMMONWEALTH OfFICE, HUMAN RIgHTS AND DEMOCRACY 2012, at http://www.hrd report.fco.gov.uk/. 
the ECOWAS Court's mandate. Finally, we address the puzzle of how the court reform campaign - triggered by a desire to increase judicial enforcement of ECOWAS economic rulesended up as a delegation of expansive human rights authority.

\section{Mechanisms of Change in International Institutions}

Toward the end of the twentieth century, the increasing number and influence of international institutions called into question the long-standing claim of realist scholars that states pursue their national interests above all else. Seeking to explain these developments, scholars spawned an extensive literature that merges rational choice institutional analysis, functional analysis, and realist assumptions about state behavior. This literature proceeds from the premise that international institutions and regimes are primarily either mechanisms for states to coordinate to achieve joint gains or vehicles for powerful nations to influence the behavior of weaker states. $^{227}$

These rationalist approaches assume that the design of international institutions is shaped by functional goals, such as addressing the structural features of underlying cooperation problems while accommodating diverse state capabilities and interests. ${ }^{228}$ These approaches also identify the mechanisms by which states control international institutions, including appointment processes, allocation of budgets, voting rules, political vetoes, and threats of noncompliance. Although state control remains incomplete, governments are expected to oppose activities that compromise important national interests. ${ }^{229}$

Rationalist scholars recognize that international institutions can change over time. In the case of global terrorism, for example, a fundamental shift in the nature of the cooperation problem resulted in modifications of institutional competences. Similarly, changes in membership, relative power, or state interests can lead to revisions of decision-making rules and other design features, such as occurred with the transformation from the General Agreement on Tariffs and Trade into the World Trade Organization. In these and other instances, however, the underlying assumption is that international institutions remain closely tethered to the interests of governments.

Historical institutionalist theory proceeds from different premises. The theory does not assume that the primary goal of the actors who populate institutions is to meet government demands. Instead, when elections, economic crises, exogenous shocks, or policy failures change state and societal preferences, institutions come under pressure to respond and evolve. Initial

\footnotetext{
227 This literature began with a 1982 special issue of the journal International Organization, which was later republished as INTERNATIONAL REGIMES (Stephen Krasner ed., 1983). Similar assumptions underpin recent rationalist international law scholarship. See, e.g., JACK L. GOLDSMITH \& ERIC A. POSNER, THE LIMITS OF INTERNATIONAL LAW (2005); ANDREW T. GUZMAN, HOW INTERNATIONAL LAW WORKS: A RATIONAL CHOICE THEORY (2008).

${ }^{228}$ E.g., Barbara Koremenos, Charles Lipson \& Duncan Snidal, The Rational Design of International Institutions, 55 INT'L ORG. 761 (2001); Barbara Koremenos, When, What, and Why Do States Choose to Delegate?, 71 LAW \& CONTEMP. PROBS. 153 (2008).

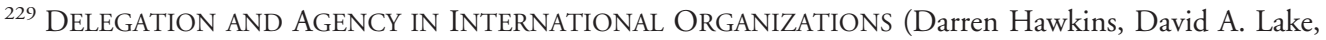
Daniel L. Nielson \& Michael J. Tierney eds., 2006); see also Curtis A. Bradley \& Judith G. Kelley, The Concept of International Delegation, 71 LAW \& CONTEMP. PROBS. 1 (2008). For a criticism of this scholarship, see Karen J. Alter, Agents or Trustees? International Courts in Their Political Context, 14 EUR. J. INT'L REL. 33 (2008).
} 
design choices and vested interests interact with shifts in the environment to produce pathdependent change. ${ }^{230}$ These contestations and the adaptation that they engender are a normal part of politics.

Contemporary historical institutionalist work focuses in depth on the modalities of institutional evolution. Early studies emphasized inertia and suggested that major policy reorientations occur primarily during critical junctures - infrequent moments of political, social, or economic upheaval when an unusual opening of political space enables the overturning of entrenched ideas and approaches. ${ }^{231}$ Recent scholarship focuses on incremental shifts that occur through political contestation and realignments of coalitions that support institutions. These more gradual changes can cumulate into transformations that are as large as, or larger than, the changes that occur during critical junctures. ${ }^{232}$

Two modalities of incremental change are especially relevant to the institutional transformations in ECOWAS. Change initially occurred via "layering" - the addition of rules, goals, or priorities that over time can become defining features of the institution. ${ }^{233} \mathrm{We}$ argue that the humanitarian interventions of the 1990s expanded the Community's mandate and created concomitantly greater constraints on state sovereignty due to expanding conceptions of regional security. These incremental shifts, in turn, created a permissive environment for nonstate actors to convince states to give the ECOWAS Court a human rights jurisdiction. The addition of private litigant access in human rights cases led to the Court's "conversion" or "redeployment," a change that allowed new actors to redirect the institution toward new goals, functions, and purposes. ${ }^{234}$

\section{Layering: From Economic Integration to Regional Security, Good Governance, and Human Rights}

As we discussed in part I, although the founding goals of ECOWAS emphasized economic integration and development, West African governments also created a limited security role for the Community. The 1978 Protocol of Non-aggression pledged member states to refrain from threats or use of force and from "encouraging or condoning acts of subversion" in neighboring

\footnotetext{
${ }^{230}$ Wolfgang Streeck \& Kathleen Thelen, Introduction: Institutional Change in Advanced Political Economies, in BEYOND CONTINUITY: INSTITUTIONAL CHANGE IN ADVANCED POLITICAL ECONOMIES 1, 7, 11 (Wolfgang Streeck \& Kathleen Thelen eds., 2005). Historical institutionalist approaches have a growing, but less well known, foothold in international relations scholarship. See, e.g., Orfeo Fioretos, Historical Institutionalism in International Relations, 65 INT'L ORG. 367 (2011); Laurence R. Helfer, Understanding Change in International Organizations: Globalization and Innovation in the ILO, 59 VAND. L. REV. 649, 666-69 (2006).

${ }^{231}$ For foundational studies that examine critical junctures, see PETER ALEXIS GOUREVITCH, POLITICS IN HARD TIMES: COMPARATIVE RESPONSES TO INTERNATIONAL ECONOMIC CRISES (1986); BARRINGTON MOORE, SOCIAL ORIGINS OF DICTATORSHIP AND DEMOCRACY: LORD AND PEASANT IN THE MAKING OF THE MODERN WOrld (1967); THEDA SKOCPOL, STATES AND SOCIAL REVOluTiOn: A COMPARATIVE ANALYSIS OF FRANCE, RUSSIA AND CHINA (1979). For a recent discussion of how critical junctures contribute to institutional change, see Giovanni Capoccia \& R. Daniel Kelemen, The Study of Critical Junctures in Historical Institutionalism, 59 WORLD POL. 341 (2007).

${ }^{232}$ E.g., Kathleen Thelen, How Institutions Evolve: The Political Economy of Skills IN Comparative-HistoriCAl PERSPeCTIVE (2004); Paul Pierson, The Path to European Integration: A Historical Institutionalist Perspective, 29 COMP. POL. STUD. 123 (1996).

233 Streeck \& Thelen, supra note 230, at 22-24.

${ }^{234}$ Id. at 26-29.
} 
countries, ${ }^{235}$ and the 1981 Protocol on Mutual Assistance and Defense promised a collective response to foreign aggression. ${ }^{236}$ For more than a decade, these Protocols remained mostly ornamental symbols of the Community's postcolonial commitment to the sovereignty and territorial integrity of its member states. ${ }^{237}$ In the early 1990s, however, Liberia's civil war spilled over into Sierra Leone, generating mass atrocities and refugee flows. In response, the member states, led by Nigeria, invoked the dormant security protocols to justify military intervention to quell the violence and prevent the spread of instability.

The humanitarian interventions of the 1990s were a watershed for ECOWAS in several respects. First, the interventions were a sharp break from the norm of noninterference in internal affairs. ${ }^{238}$ The collective response to mass atrocities on the territory of one of their own, despite vociferous protestations by some francophone member states, revealed that African governments were willing to limit national sovereignty to achieve other Community goals. Political leaders initially identified these goals as the immediate need to restore peace and security in particular countries. Over time, however, the goals expanded to a broader conception of regional conflict prevention that included constitutional transitions of power, good governance, and human rights. Court reform advocates stressed that this expansion "reoriented thinking [in West Africa] about jurisdictional sovereignty."239

Second, the interventions exposed gaps in ECOWAS legal instruments that created opportunities for a wider overhaul of the Community. The member states' decision to put security issues on a firmer legal footing occurred at the same time as the high-level review of the integration project and the decision to create the ECOWAS Court. The Committee of Eminent Persons, convened in 1991 to assess the shortcomings of ECOWAS's founding period and propose institutional reforms, gave equal emphasis to security and economic issues. The committee defined security broadly as including "peace and stability" within states, and it highlighted that the "whirlwind of political reform sweeping through various parts of the world [has not] exempted West Africa, where demands for democratisation, based on political pluralism and respect for human rights, have multiplied in recent times." ${ }^{240}$ Whereas the 1975 ECOWAS Treaty " $\mathrm{d}[\mathrm{id}]$ not mention human rights and completely avoid[ed] any use of human rights language," 241 following the Committee's recommendations the 1993 Revised Treaty identified the African Charter as a "fundamental principle" of ECOWAS. ${ }^{242}$ These revisions created another facilitating condition for the member states' later decision to give the ECOWAS Court jurisdiction over human rights.

235 Supra note 40, Arts. 1, 2.

236 Supra note 41.

237 These protocols reflected the then prevalent idea of a Pax Africana, wherein African leaders would manage their own internal affairs. COMFORT ERO, WAHEGURU PAL SINGH SIDHU \& AUGUSTINE TOUREET (RAPPORTEURS), TOWARD A PAX WeSt AFriCANA: BuILding PEACE IN A TROUbled Sub-REgION (2001), available at http://www.ipinst.org/media/pdf/publications/pdf_report_pax_w_africana.pdf.

${ }^{238}$ Comfort Ero, ECOMOG: A Model for Africa, in BUILDING STABILITY IN AFRICA: CHALLENGES FOR THE NEW MiLlENNIUM 97 (Jakkie Cilliers \& Annika Hildung-Norberg eds., 2000).

${ }^{239}$ E.g., Telephone interview with Human Rights Advocate A, supra note 91.

${ }^{240}$ Final CEP Report, supra note 14, at 37; see also VILJOEN, supra note 134, at 482 ("as the winds of democracy swept authoritarianism and militarism from the continent in a post-Cold War world, . . . human rights became mainstreamed into all forms of subregional cooperation").

${ }^{241}$ Ebobrah, Critical Issues, supra note 112, at 3.

${ }^{242} 1993$ Treaty, supra note 37, Art. 4(g). 
Third, although the member states justified the interventions on humanitarian grounds, ECOMOG forces sadly added to the humanitarian tragedy. The "numerous reports of ECOMOG peacekeepers engag[ing] in looting, expropriation and theft" and accusations of "human-rights abuses, and sexual exploitation of women and children . . bespoke of the lack of discipline and accountability of the armed forces of the countries involved, especially Nigeria." ${ }^{243}$ The abuses and subsequent lack of accountability highlighted that the Community had "not done enough to incorporate human rights in its conflict resolution initiative[s]." ${ }^{244}$ These events also triggered "a re-examination of the role of human rights in guaranteeing regional stability and security in ECOWAS," 245 adding to the "demands for democratisation, based on political pluralism and respect for human rights" from civil society groups that now had input into Community decision making. ${ }^{246}$

Taken together, the layered-on addition of these broad security goals fundamentally shifted ECOWAS's normative orientation, a change exemplified by the 1999 Conflict Prevention Protocol and the 2001 Good Governance Protocol discussed in part II. This shift helps to explain why the arguments of court reform advocates resonated with government and Community officials, who saw advantages to fulfilling the pledge to give the ECOWAS Court "the power to hear . . . cases relating to violations of human rights, ${ }^{247}$ and to taking a concrete step toward creating a more "people-centered" Community. ${ }^{248}$ Compared to authorizing collective military intervention in a member state, empowering the Court to adjudicate individual human rights violations was a relatively modest step.

\section{Redeployment: Why Human Rights Have Eclipsed Economic Issues in the ECOWAS Court}

The expansion of the ECOWAS Court's jurisdiction to include human rights did not supplant the Court's original mandate to interpret and apply Community economic rules. Seen from this perspective, the 2005 Protocol is an example of "layering" - the addition of a new goal or priority to an existing institution that also retains its original mandate. In practice, however, the ECOWAS Court functions primarily as an international human rights tribunal, and its docket is bereft of cases challenging violations of Community economic rules. The Court's transformation is thus more accurately viewed an example of "redeployment" or "conversion," a change that allows a new set of actors to fundamentally reorient an institution in a new direction.

The absence of a practical role for the Court in enforcing regional economic rules does not mean that member states have abandoned cooperation in that area. ECOWAS continues to advertise its one-sentence mission as "promot[ing] economic integration in all fields of economic activity," ${ }^{449}$ and the Community has made meaningful policy steps toward this goal. For example, the 2005 Protocol enhanced the Court's role in overseeing compliance with

${ }^{243}$ Arthur, supra note 45, at 16.

${ }^{244}$ KABIA, supra note 43 , at 87.

245 Chidi Anselm Odinkalu, ECOWAS Court of Justice in the Protection of Human Rights, in COMPENDIUM OF THE INTERNATIONAL CONFERENCE ON “THE LAW IN THE PROCESS OF INTEGRATION IN WeST AFRICA,” supra note 93, at 185.

${ }^{246}$ KUFUOR, supra note 12, at 161; see also id., at 49-50 (discussing NGO participation).

2472001 Good Governance Protocol, supra note 49, Art. 39.

${ }^{248}$ Interview with Mohamed Ibn Chambas, Executive Secretary of ECOWAS, supra note 91.

${ }^{249}$ ECOWAS in Brief(n.d.), at http://www.comm.ecowas.int/sec/index.php?id=about_a\&lang=en. 
ECOWAS economic rules by permitting preliminary references from national courts and authorizing enforcement actions by the ECOWAS Commission. ${ }^{250}$ In addition, since the 2006 overhaul of the Community, it can be argued persuasively that ECOWAS rules are now directly applicable in national legal orders, with the consequence that judges should, in theory, be able to apply those rules directly.

But significant barriers to enforcing economic rules persist. As a formal matter, although ECOWAS protocols are directly applicable, the member states have not created "legislative provisions that 'speak to' the relations between [Community and domestic] legal systems." ${ }^{251}$ In addition, national judges and lawyers have little knowledge of how the ECOWAS legal system is designed to function. Without formal rules or habituated practices, national judges are disinclined to invalidate conflicting national laws or to refer cases to the ECOWAS Court.

Member states might have reduced these barriers had the 2005 Protocol given private traders direct access to the ECOWAS Court. The absence of such access from the 2005 reforms is one of the most puzzling aspects of the Court's transformation. It is especially so in the wake of the Afolabi case, which directly raised the issue of economic actors not having standing before the Court. $^{252}$

Explaining why access for private traders vanished from the court reform campaign requires us to search for "dogs that did not bark," an inquiry that is necessarily no more than suggestive. Our research reveals two plausible explanations for this omission: no regionally organized constituency sought the vigorous enforcement of ECOWAS economic rules, and court reform advocates strategically conflated human rights and economic freedoms and then sacrificed direct access of one to achieve the other.

The first explanation is true but insufficient. Economic interest groups are present in West Africa, and they are aware of the many obstacles to intraregional trade. We interviewed the leadership of one of these groups, the National Association of Nigeria Traders (NANTs), whose officials are knowledgeable about the ECOWAS legal system. ${ }^{253}$ They identified specific practices in Ghana and Nigeria that violate Community economic rules, including border closings and impediments to establishing a business, and they showed us letters of complaint filed with the ECOWAS Commission. To enhance their ability to challenge these violations, NANTs recently asked West African governments to allow private firms direct access to the Court. $^{254}$

NANTs was not, however, part of the 2005 court reform campaign. One impediment to its inclusion was that the group is nationally organized, whereas ECOWAS rules only allow for participation by regional groups. But ECOWAS officials could have facilitated the mobilization of economic groups, or national traders with a presence in multiple countries could have organized regionally. Perhaps such groups did not see any benefit from using ECOWAS institutions to promote their objectives. But then one has to ask why they would not adopt a strategy that worked so well for human rights groups. Our answer is that West African

\footnotetext{
${ }^{250}$ See the sub-subsection in part II entitled "A broad authority for human rights suits, but a narrower mandate for economic cases" (explaining these provisions of the 2005 Protocol).

${ }^{251}$ Ebobrah, Critical Issues, supra note 112, at 15.

${ }^{252}$ See subsection in part II entitled "The Afolabi Case: Justice Denied for Private Litigants."

${ }^{253}$ The organization's website is at http://nants.org/.

${ }^{254}$ Crusoe Osagie, West Africa: Traders Task ECOWAS on Regional Integration, THIS DAY (Aug. 29, 2011), at http://allafrica.com/stories/201108300754.html.
} 
governments benefit from maintaining barriers to intraregional trade and that these benefits, at least in the current political and economic climate, outweigh the advantages of achieving a functioning common market. In the words of a recent NANTs newsletter, "Member States did not desire the Court to be an engine for realizing the economic integration objective." 255

Although economic groups did not gain direct access to the Court in the 2005 reforms, human rights groups did, and they have since capitalized on this access by filing numerous suits against governments. To convert the Court to their objective, these groups argued that the Community's recently endorsed goal of protecting human rights and its long-standing plan to promote economic development were one and the same. Many West African scholars, NGOs, and litigants strategically conflate the goals of economic integration and the protection of human rights. For example, one such scholar, Nneoma Nwogu, points to provisions in the 1993 Treaty that embrace social values, including human rights, and argues that these values are fundamental to the Community's economic motivations. ${ }^{256}$ Our interviews revealed a similar tendency to elide these objectives. A human rights attorney told us that ECOWAS was created in response to problems, such as Nigeria's expulsion of West Africans in the 1970s, that implicated both economic and human rights issues. ${ }^{257}$ The applicant's lawyer in the Afolabi case also invoked both the African Charter's human right to freedom of movement and ECOWAS's free-movement obligations, seemingly drawing on the growing human rights zeitgeist to bolster Afolabi's legal claim. ${ }^{258}$

Court reform advocates may have genuinely believed that human rights encompass economic freedoms, but they also must have been aware that the two legal fields intersect only in part. It is more likely that advocates strategically conflated the two fields to suggest that giving the Court a human rights mandate would also further ECOWAS's primary objective of promoting regional integration. Governments and ECOWAS officials were seemingly happy to go along with this diversion.

The strategy worked. But as the NANTs newsletter explains, the ability to file human rights complaints with the ECOWAS Court does not help to challenge most economic violations, such as a Ghanaian law that privileges domestic traders and requires significant cash investments for foreigners to establish a business. ${ }^{259}$ In reality, then, the decision to grant direct access only for human rights reflects a political choice to prioritize one set of Community goals over another. The ironic result is that, notwithstanding that the Afolabi suit triggered a major revision of the ECOWAS Court's protocol, litigants like Afolabi are still unable to challenge the many barriers to intraregional trade in West Africa.

Our principal theoretical claim is that international institutions, like their domestic counterparts, respond and adapt to changing norms and societal pressures. Even if rational func-

\footnotetext{
255 Sovereignty, Supra-nationality and Trade: The Case of ECOWAS Laws, 2 ECOWAS VANGUARD, Feb. 2013, at 7 , available at http://nants.org/wp-content/uploads/2013/03/Soveriegnty-Supranationality-and-Trade-TheCase-of-ECOWAS-Laws-ECO-VANGUARD-FEB-2013-English-Edition.pdf.

${ }^{256}$ Nwogu, supra note 95, at 348-49; see also OPPONG, supra note 65, at 148 (asserting that the "links between economic development and human rights are too obvious to merit discussing").

257 Telephone interview with Human Rights Advocate B, supra note 48.

258 Afolabi v. Nigeria, Judgment, supra note 73, para. 7.

259 Sovereignty, Supra-nationality and Trade, supra note 255, at 7.
} 
tionalist goals shape an international institution's initial design, those objectives do not control how the institution evolves over time. We have suggested that the ECOWAS Court's transformation is a result of the incremental layering on of new security roles for the Community together with civil society pressures to entrench respect for human rights. ECOWAS's contested involvement in humanitarian intervention brought human rights concerns into Community politics. Eager to prevent civil wars and violent unrest in the region, ECOWAS assumed a conflict prevention role and then expanded its activities to include promoting constitutional transitions, good governance, and human rights. These developments created a permissive environment for civil society groups and ECOWAS judges to lobby member states to give the Court a human rights jurisdiction, in part by arguing that doing so would also further economic integration. In practice, however, the choices made by government leaders, Community officials, and NGOs implicitly maintained the barriers to judicial enforcement of regional economic rules while facilitating a wave of human rights complaints by private litigants that completed the Court's redeployment.

\section{CONCLUSION: HOW DEEP IS ECOWAS'S COMMITMENT TO PROTECTING HUMAN RIGHTS?}

This article has examined the transformation of the ECOWAS Community Court of Justice into a new international human rights court for West Africa. Our study reveals that the ECOWAS Court belongs on any list of human rights tribunals. Most such lists are limited to judicial and quasi-judicial bodies linked to specific human rights treaties, such as the African Charter system and the African Commission and Court on Human and Peoples' Rights. Although the ECOWAS Court exercises jurisdiction over fewer states, it is at least as active in adjudicating human rights violations as are these two continent-wide institutions. The Court issues judgments quickly and provides legally binding remedies to victims who have direct access to the Court without exhausting local remedies. Moreover, as scholars such as Solomon Ebobrah have shown, ECOWAS judges have addressed many issues that have yet to come before the African Commission or Court and are making important contributions to regional human rights jurisprudence. ${ }^{260}$

In this last part, we briefly consider three issues relating to whether a redeployed international human rights court can survive in the rough and tumble world of African politics. The first issue concerns the sincerity of states' commitment to the ECOWAS Court's human rights jurisdiction. The second is whether the ECOWAS Court is likely to face a backlash similar to those that the East African Court of Justice and the Tribunal of the Southern African Development Community have experienced. Finally, we discuss whether the overlapping human rights competences between the subregional courts and the African Charter system will contribute to the fragmentation of international law in ways that undermine legal certainty and respect for human rights.

${ }^{260}$ E.g., Solomon T. Ebobrah, Human Rights Developments in African Sub-regional Economic Communities During 2009, 10 AFR. HuM. RTS. J. 233 (2010); Solomon T. Ebobrah, Human Rights Developments in African Subregional Economic Communities During 2010, 11 AFR. HUM. RTS. J. 216 (2011); Ebobrah, Critical Issues, supra note 112 . 
Skeptics of the Court's expansion into human rights have suggested that the 2005 Protocol was an insincere commitment by ECOWAS member states. ${ }^{261}$ They have intimated that West African leaders agreed to the Protocol not out of a desire to remedy human rights violations in the region but rather because they expected that the ECOWAS Court, whatever its powers on paper, would have little influence on national laws or practices. ${ }^{262}$

We found no evidence to support this claim. The 2005 Protocol's specific grant of "jurisdiction to determine cases of violation of human rights that occur in any member state" was drafted, vetted, and approved in the same manner as other ECOWAS legal instruments. If some government officials predicted that the Protocol would be ignored, they were misinformed or turned a blind eye to the plain language of the agreement. ${ }^{263}$ States also declined to extend private litigant access to economic cases, a decision that suggests a careful choice about which types of suits private litigants would be permitted to file. It is noteworthy that states later rejected plausible proposals to curtail the Court's human rights authority and adopted reforms that strengthened the independence and quality of ECOWAS judges. Taken together, these actions suggest that West African governments want the Court to review human rights complaints.

As noted in the introduction, the ECOWAS Court's expansion into human rights is not unique. In the 1970s, the European Court of Justice made a similar shift, albeit for different reasons, ${ }^{264}$ as did (more recently) the courts associated with two other subregional economic communities in Africa-the East African Court of Justice and the Tribunal of the Southern African Development Community. Unlike the situation of the ECOWAS Court, however, these expansions occurred via judicial lawmaking. ${ }^{265}$ In Europe, member states later ratified the ECJ's jurisprudential advances, most recently when they adopted the Lisbon Treaty that made the EU Charter of Fundamental Rights legally binding. ${ }^{266}$ The consequences of the bold judicial assertions of human rights competence by the EACJ and SADC Tribunal are still unfolding, but early evidence indicates that both courts have faced substantial opposition from governments. $^{267}$

In response to an early controversial ruling involving appointments to the East African Legislative Assembly, member states amended the East African Community Treaty to divide the East African Court of Justice into two divisions (first instance and appellate), impose strict time

\footnotetext{
261 See, e.g., HEATHER SMITH-CANNOY, InSINCERE COMMITMENTS: HUMAN RigHTS TREATIES, ABUSIVE STATES, AND CITIZEN ACTIVISM 9 (2012).

${ }^{262}$ A variant of this argument asserts that West African leaders adopted the 2005 Protocol to signal to international organizations, foreign donors, or domestic interest groups a seemingly real but, in fact, temporary or disingenuous commitment to human rights or to other goals desired by those actors. For a critique of the claim that human rights treaty ratifications are "costless signals," see Ryan Goodman and Derek Jinks, Measuring the Effects of Human Rights Treaties, 14 EUR. J. INT'L L. 171, 179 (2003).

263 See BETH SimMONS, MOBILIZING FOR HUMAN RigHTS 78 (2009) (explaining that states often "underestimate the probability that they will be pressured to live up to their international treaty commitments in the years to come").

264 See, e.g., Gráinne de Búrca, The Road Not Taken: The European Union as a Global Human Rights Actor, 105 AJIL 649, 687 (2011).

${ }^{265}$ Laurence R. Helfer \& Karen J. Alter, Legitimacy and Lawmaking: A Tale of Three International Courts, 14 THEORETICAL INQUIRIES IN L. 479, 492-93 (2013); see also Karen J. Alter \& Laurence R. Helfer, Nature or Nurture? Judicial Law-Making in the European Court of Justice and the Andean Tribunal of Justice, 64 INT'L ORG. $563(2010)$.

266 De Búrca, supra note 264, at 670-73.

267 See sources cited supra notes 9 and 260.
} 
limits on filing complaints, and add new grounds for removing and suspending judges. ${ }^{268}$ The Court later interpreted the Treaty as conferring a limited mandate to adjudicate human rights issues. Government officials have since repeatedly challenged the Court's jurisdiction over human rights suits. ${ }^{269}$ In Southern Africa, the reaction has been more severe. Beginning in 2008, the SADC Tribunal upheld suits by white farmers challenging land seizures in Zimbabwe as violating the human rights and rule-of-law provisions in the SADC Treaty. ${ }^{270}$ President Robert Mugabe responded to these decisions by mobilizing the SADC's highest political body to suspend the Tribunal pending the drafting of a new protocol that strips its jurisdiction over complaints from private litigants. These measures have ended, at least for the foreseeable future, the SADC Tribunal's ability to adjudicate human rights claims. ${ }^{271}$

The ECOWAS Court's experience is different in several respects. First, unlike their colleagues in eastern and southern Africa, ECOWAS judges do not need to finesse whether they have a human rights competence, because member states have expressly given the Court jurisdiction to review and remedy human rights violations. Second, West African governments conferred this jurisdiction on the Court for reasons internal to the Community-namely, ECOWAS's growing role in regional security and a desire to facilitate constitutional transitions and good governance. Third, the supranational status of ECOWAS is further advanced than the other two subregional integration projects. In 2006, ECOWAS member states made Community protocols directly applicable in national legal orders without the need for ratification and enhanced the supranational authority of ECOWAS institutions. By contrast, the SADC and, to a lesser extent, EAC remain predominantly interstate bodies whose secretariats are largely reactive to shifts in governments' commitments to community and integration. Fourth, the ECOWAS Court's human rights mandate enjoys the strong support of the ECOWAS Commission, whose officials can help assess the political landscape and redirect opposition to the Court in ways that address member states' concerns without compromising the judges' independence. Taken together, these differences explain why the ECOWAS Court's human rights mandate stands on politically and legally firmer footing than that of its subregional neighbors, and why the Court has survived unpopular judgments and a campaign to curtail its jurisdiction.

To be sure, the challenge of eliciting compliance with the ECOWAS Court's judgments remains formidable. ${ }^{272}$ But this problem must be put in perspective. The European Court of Human Rights and the Inter-American Court of Human Rights took decades to establish their authority, whereas subregional tribunals in Africa are still in their infancy. ECOWAS judges have demonstrated political savvy as they navigate this fraught terrain. The judges have been circumspect in interpreting international law and in modulating the remedies that they award to successful applicants. Such strategies help to establish a politically safe space for the

\footnotetext{
${ }^{268}$ Henry Onoria, Botched-Up Elections, Treaty Amendments and Judicial Independence in the East African Community, 54 J. AFR. L. 74, 83 (2010).

${ }^{269}$ Gathii, supra note 161, manuscript at 24-27 (describing the backlash by governments following the Nyong'o election case). The precise relationship between the timing of the treaty amendments and their influence on the EACJ's human rights case law remains to be explored.

270 Treaty of the South African Development Community, Aug. 17, 1992, 32 ILM 116 (1993), at http:// www.sadc.int/documents-publications/sadc-treaty/.

${ }^{271}$ E.g., Frederick Cowell, The Death of the Southern African Development Community Tribunal's Human Rights Jurisdiction, 13 HUM. RTS. L. REV. 153 (2013); Erika de Wet, The Rise and Fall of the Tribunal of the Southern African Development Community: Implications for Dispute Settlement in Southern Africa, 28 ICSID REV. 45 (2013).

272 See supra notes 218-26 and accompanying text.
} 
Court - a space in which it can condemn clear violations of human rights and pressure governments outside the courtroom to comply with its rulings.

Many government officials, human rights groups and lawyers anticipate that the member states will eventually specify which human rights treaties can be adjudicated by the ECOWAS Court, add an exhaustion of domestic remedies requirement, and create an appellate review mechanism. These revisions, if they do occur, should not be seen as rebukes of either the Court or its judges. Rather, such revisions are more likely to reflect a maturing legal system that is evolving in conjunction with fundamental reorientations of ECOWAS objectives.

A final issue concerns whether the multiplicity of human rights adjudicatory bodies is problematic insofar as it exacerbates the fragmentation of international law in Africa. Scholars who express concerns about fragmentation cite the lack of clarity from inconsistent legal rulings and the fear that governments may use that inconsistency to follow the most lenient interpretations of their human rights obligations. ${ }^{273}$ The ECOWAS Court contributed to these fragmentation concerns in one high-profile case-a judgment against Senegal that it violated the rights of former Chadian President Hissein Habré by taking steps to prosecute him for torture and other international crimes. ${ }^{274}$ The Court disallowed the prosecution, and in a later ICJ proceeding, Senegal argued that it had delayed prosecuting Habré due to its obligation to comply with the ECOWAS Court judgment. ${ }^{275}$

Although other examples may arise, the adjudication of human rights by the ECOWAS Court enhances, on balance, the clarity of international law and raises, not lowers, human rights protections in West Africa. For civil society groups, the ECOWAS Court and other subregional tribunals offer a way to minimize the "obstruction, haggling, [and] delay" that many observers associate with the continental human rights system. ${ }^{276}$ For lawyers, subregional litigation provides a corrective to the limited avenues of legal recourse available to victims of rights abuses in Africa. ${ }^{277}$ For judges on subregional courts, the adjudication of human rights provides an opportunity to expand their dockets, develop legal doctrine, and issue rulings that are relevant to stakeholders. If the courts' decisions also complement or extend the norms of the African Charter, so much the better. ${ }^{278}$

This conclusion has provided only a cursory overview of the many issues implicated by the burgeoning of international human rights litigation in Africa. The contemporaneous move

${ }^{273}$ E.g., VILJOEN, supra note 134, at 437 (warning that the existence of multiple international venues for adjudicating human rights claims "may lead to divergence in jurisprudence and to forum shopping, where quasi-judicial and judicial institutions are compared and played off against one another").

${ }^{274}$ Habré v. Senegal, Judgment, supra note 200, paras. 58, 61.

275 Questions Relating to the Obligation to Prosecute or Extradite (Belg. v. Sen.), 2012 ICJ REP. 1, para. 110 (July 20). The ICJ rejected Senegal's argument, holding that "Senegal's duty to comply with its obligations under the [UN] Convention [Against Torture] cannot be affected by the decision of the ECOWAS Court of Justice." Id., para. 111. In fact, the ECOWAS Court had left open the option of trying Habré before an ad hoc or international tribunal. Habré v. Senegal, Judgment, supra note 200, paras. 58, 61. In 2012, Senegal and the African Union agreed to create a hybrid court within the Senegalese judicial system, known as the Extraordinary African Chambers, with jurisdiction over genocide, crimes against humanity, war crimes, and torture committed in Chad in the 1980s. Sangeeta Shah, Questions Relating to the Obligation to Prosecute or Extradite (Belgium v Senegal), 13 HUM. RTS. L. REV. 351, 363-66 (2013).

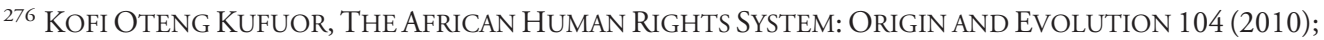
see also Solomon Ebobrah, Litigating Human Rights Before Sub-regional Courts in Africa: Prospects and Challenges, 17 AFR. J. INT'L \& COMP L. 78, 87 (2009).

277 Duffy, supra note 212, at 182-87.

${ }^{278}$ See KUFUOR, supra note 275, at 105; VILJOEN, supra note 134, at 453-55. 
into human rights by three similarly situated subregional community courts, together with the increasing activity of the African Charter institutions, creates a natural experiment to examine the different ways that government officials, judges, and civil society groups mobilize and navigate the often fraught politics of human rights compliance. Our initial review of this experiment suggests that the manner in which international courts acquire jurisdiction over human rights is legally and politically consequential. The mode of acquisition affects issues such as the strategies of litigants, the interpretive methodologies of judges, the remedies awarded, and the responses of governments to the courts' exercise of their newly acquired authority. ${ }^{279}$ The explicit delegation of human rights authority also provides international judges with a political buffer as they take on the challenging task of adjudicating state violations of human rights.

279 See Joost Pauwelyn \& Manfred Elsig, The Politics of Treaty Interpretation: Variations and Explanations Across International Tribunals, in INTERDISCIPLINARY PERSPECTIVES ON INTERNATIONAL LAW AND INTERNATIONAL Relations: THE STATE OF THE ART 445 (Jeffrey L. Dunoff \& Mark A. Pollack eds., 2013) (suggesting a connection between the institutional structure of international courts and the types of treaty interpretation adopted by their judges). 